\title{
Geophysical characterization of buried active faults: the Concud Fault (Iberian Chain, NE Spain)
}

\author{
Óscar Pueyo Anchuela ${ }^{1,2}$ - Paloma Lafuente ${ }^{1} \cdot$ Luis Arlegui $^{1} \cdot$ Carlos L. Liesa $^{1}$. \\ José L. Simón ${ }^{1}$
}

Received: 16 February 2015 / Accepted: 3 December 2015

(C) Springer-Verlag Berlin Heidelberg 2015

\begin{abstract}
The Concud Fault is a 14-km-long active fault that extends close to Teruel, a city with about 35,000 inhabitants in the Iberian Range (NE Spain). It shows evidence of recurrent activity during Late Pleistocene time, posing a significant seismic hazard in an area of moderate-to-low tectonic rates. A geophysical survey was carried out along the mapped trace of the southern branch of the Concud Fault to evaluate the geophysical signature from the fault and the location of paleoseismic trenches. The survey identified a lineation of inverse magnetic dipoles at residual and vertical magnetic gradient, a local increase in apparent conductivity, and interruptions of the underground sediment structure along GPR profiles. The origin of these anomalies is due to lateral contrast between both fault blocks and the geophysical signature of Quaternary materials located above and directly south of the fault. The spatial distribution of anomalies was successfully used to locate suitable trench sites and to map non-exposed segments of the fault. The geophysical anomalies are related to the sedimentological characteristics and permeability differences of the deposits and to deformation related to fault activity. The results illustrate the usefulness of geophysics to detect and map non-exposed faults in areas of moderate-to-low tectonic activity where faults are often covered by recent pediments that obscure geological evidence of the most recent earthquakes. The results also highlight the importance of
\end{abstract}

Óscar Pueyo Anchuela

opueyo@unizar.es

1 Departamento de Ciencias de la Tierra, Universidad de Zaragoza, C/Pedro Cerbuna 12, 50009 Zaragoza, Spain

2 Centro Uned-Calatayud, Avda. San Juan El Real, $n^{\circ} 1$, 50300 Calatayud, Zaragoza, Spain applying multiple geophysical techniques in defining the location of buried faults.

Keywords Active fault $\cdot$ Seismic hazard $\cdot$ Geophysical survey $\cdot$ Magnetometry $\cdot$ EM induction $\cdot$ GPR $\cdot$ Trench

\section{Introduction}

Paleoseismological characterization of active faults requires a multidisciplinary, multiscale approach. This includes, among others, field mapping, outcrop observations and collection of samples for dating and sedimentological interpretation. Often good outcrops for detailed observation are not available, requiring the excavation of paleoseismological trenches to observe the fault and evaluate stratigraphic relations. Identifying the optimal location for trench excavation is of paramount importance to ensure that the fault is exposed and to minimize potential investigative problems related to the logistics design, environmental impact assessment and safety planning. Structures with low rates of activity or long interseismic intervals can be obscured at the surface by erosion or coeval and later sedimentation. Detailed mapping of active faults that are not expressed at the surface can also be problematic for seismic hazard assessment in urban areas. Geophysical surveys can assist in the location of active structures in the subsurface, and integrating the results from multiple geophysical methods can provide detailed information on the nearsurface conditions. From these, ground penetrating radar (GPR), seismic and electromagnetic or resistivity methods have been shown to be particularly useful (e.g., Benson and Mustoe 1995; Suzuki et al. 2000; McBride and Stephenson 2003; Wise et al. 2003; Khesin 2004; Nguyen et al. 2007; 
Štěpančíková et al. 2011; Fischer et al. 2012; Dujardin et al. 2014).

The chosen methods should be able to discriminate geophysical signatures associated with tectonic deformation such as the lateral sharp contrasts between geophysical properties on the hanging and footwall blocks and/or variations in the physical properties and geometry of recent syn-tectonic deposits. This type of geophysical analysis can help to fill the scale gap between trench and map scale observations, by allowing extrapolation of information to sections of the fault system that are not exposed at the surface or at deeper stratigraphic levels.

Geophysical surveys are typically applied to locate, map and characterize faults in the shallow subsurface (e.g., Demanet et al. 2001a, b; Gwendolyn et al. 2005; Vanneste et al. 2008; Suski et al. 2010), and provide an indirect approach to measure the physical properties associated with deformed sediments. Magnetic susceptibility or remanence, conductivity or resistivity, rigidity or density are common properties that can be analyzed from geophysical techniques. These changes across discrete boundaries such as faults are sharper than those of other origins. Changes in those properties across net boundaries, such as faults, are sharper than those of other origins (e.g., lateral facies changes in sedimentary bodies). In the case of active faults with syn-tectonic deposits, the geophysical signature is caused by a combination of: (1) lateral contrast between physical properties of pre-tectonic materials in each fault block, (2) thickness distribution and physical properties of the syn-tectonic materials and (3) anomalies related to local hydrogeological changes associated with permeability of the shallow sediments or bedrock. In summary, near-surface faults can be identified by direct or indirect indicators linked to the fault evolution, sedimentary activity record or permeability changes between both fault blocks.

In this paper, we apply several different geophysical methods to evaluate the subsurface conditions along part of the active Concud Fault within the Iberian Chain (NE Spain) in the shallow subsurface. In order to obtain the best resolution, we used magnetometry, electromagnetic (EM) multifrequency surveys and GPR with unshielded and shielded antennas. The geophysical results were used to determine the location of a paleoseismic trench described in detail in Lafuente et al. (2014). Here, we describe the geophysical results, assess the utility of the methods in locating the trench site, and compare the geophysical results to trench observations.

\section{Geological and structural setting}

During the Neogene and the Quaternary, a network of extensional basins developed at the eastern sector of the
Iberian Chain (NE Spain, Fig. 1). These basins represent the onshore deformation of the Valencia Trough (Álvaro et al. 1979; Vegas et al. 1979; Roca and Guimerà 1992) and are bound by active faults that contribute to earthquake hazard in the region (e.g., Simón et al. 2015). Two rift episodes have been distinguished (Simón 1982, 1983): the first one (Late Miocene) produced the NNE-SSW trending Teruel graben, while the second one (Late Pliocene-Quaternary) gave rise to the NNW-SSE trending Jiloca graben and reactivated the Teruel graben.

The active Concud Fault, the focus of this study, is located at the junction of the Jiloca and Teruel grabens (Fig. 1). The Teruel graben is a half graben bound on the east, by large $\mathrm{N}-\mathrm{S}$ striking faults. Early Late Miocene (Vallesian) to Late Pliocene-earliest Pleistocene (Villafranchian) sedimentary deposits that fill the basin were divided by Godoy et al. (1983a, b) into informal units, including Rojo 1 (red lutites with some conglomerates, sandstones and limestones, Vallesian), Páramo 1 (lacustrine carbonates, Turolian), Rojo 2 (red-orange lutites, Upper Turolian-Ruscinian), Páramo 2 (lacustrine carbonates, Ruscinian) and Rojo 3 (red lutites, Ruscinian-Villafranchian). The Jiloca asymmetric graben shows an overall NNW-SSE trend that results from an en-echelon arrangement of NWSE striking normal faults. The largest faults are located at the eastern side of the basin and include, from north to south, the Calamocha, Sierra Palomera and Concud Faults. The Jiloca graben is filled by a Late Pliocene to Pleistocene sedimentary sequence that consists of alluvial fan, pediment and episodic palustrine deposits.

Little information is available about recent activity and paleoseismology of the Calamocha and Sierra Palomera structures. The Calamocha fault is a pure normal fault oriented NNW-SSE, which separates the northern part of the Jiloca graben from the Neogene infill of the Calatayud basin. In the central segment, it accommodates a total net slip of about $220 \mathrm{~m}$, since Late Pliocene time, indicating an average slip rate of $0.06-0.09 \mathrm{~mm} /$ year. Two outcrops studied close to the town of Calamocha indicated that the fault has undergone recurrent movement during the Late Pleistocene (Simón et al. 2012; Martín Bello et al. 2014). The offset along the Sierra Palomera fault cannot be directly estimated, since no appropriate recent sedimentary markers have been identified. However, based on a realistic morphostructural reconstruction, Rubio and Simón (2007) interpret a total vertical offset of 530-540 m (post-3.6 Ma) and a long-term slip rate ranging from 0.11 to $0.15 \mathrm{~mm} /$ year. Thickness variation patterns of the Quaternary sedimentary infill of the central Jiloca basin (Rubio and Simón 2007), as well as local scarps offsetting the surface of Late Pleistocene alluvial fans (García Lacosta et al. 2014), demonstrate that the Sierra Palomera fault is also an active structure. 
Fig. 1 Schematic geological map of the Jiloca and Teruel grabens (modified from Rubio and Simón 2007). Inset shows its location in the Iberian Peninsula. The location of Fig. 2 is indicated by red box

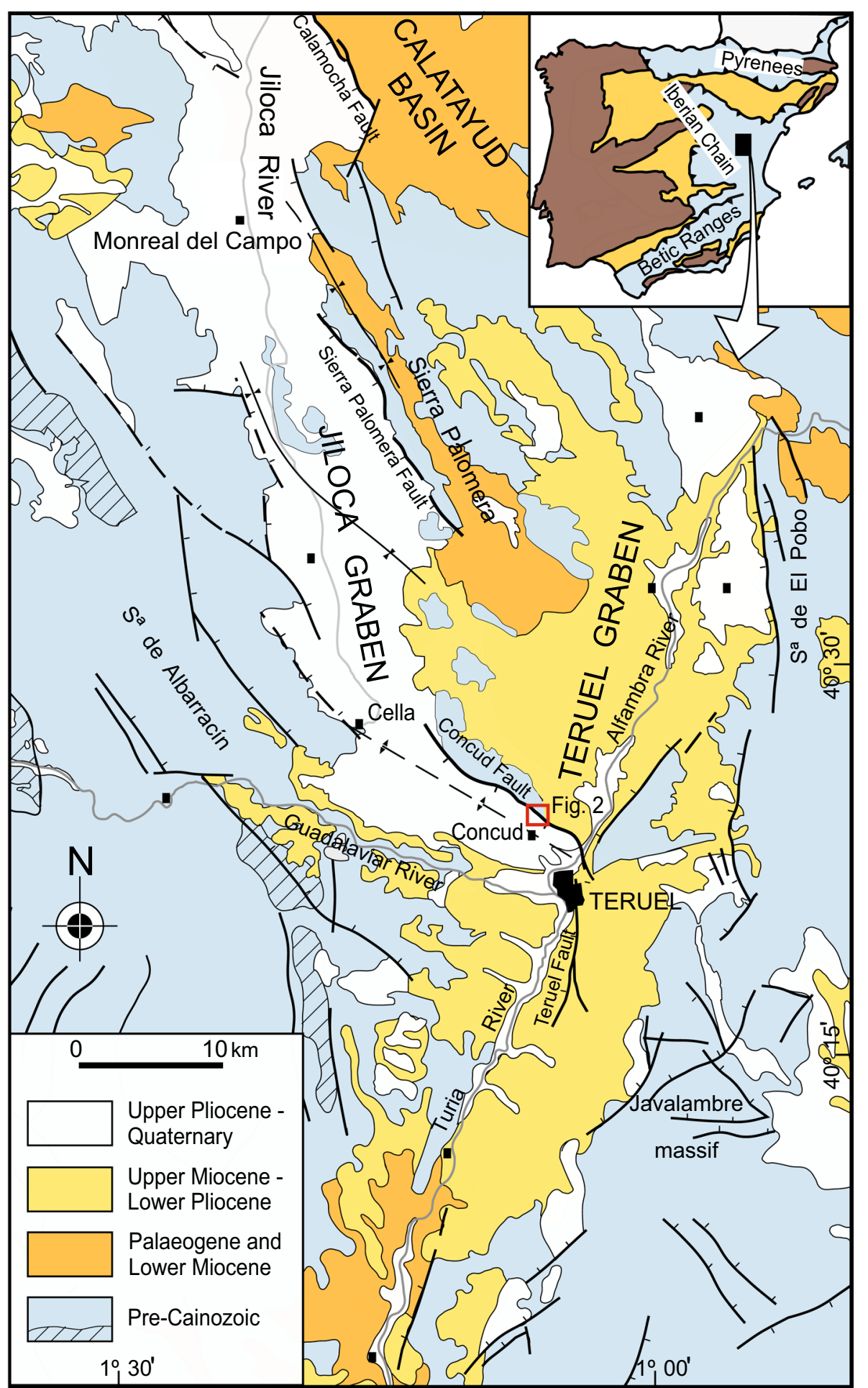

The geological record of recent activity of the Concud Fault is much more robust. Detailed mapping of this fault defines a continuous 14.2-km-long structure with an overall NW-SE strike, which veers toward N-S at its southern end, where it approaches the N-S striking Teruel fault (Fig. 1). The Quaternary, mainly alluvial deposits of the hangingwall block, is juxtaposed against Triassic and Jurassic units of the footwall block at the northwestern end, and against Neogene units of the Teruel basin at the southeastern end. A single large fault trace characterizes the northern and southern part of the fault, while two parallel traces are present in the central section (Fig. 2). Neogene units of the footwall are deformed into a monocline, indicating that the style of deformation is similar to that described by 


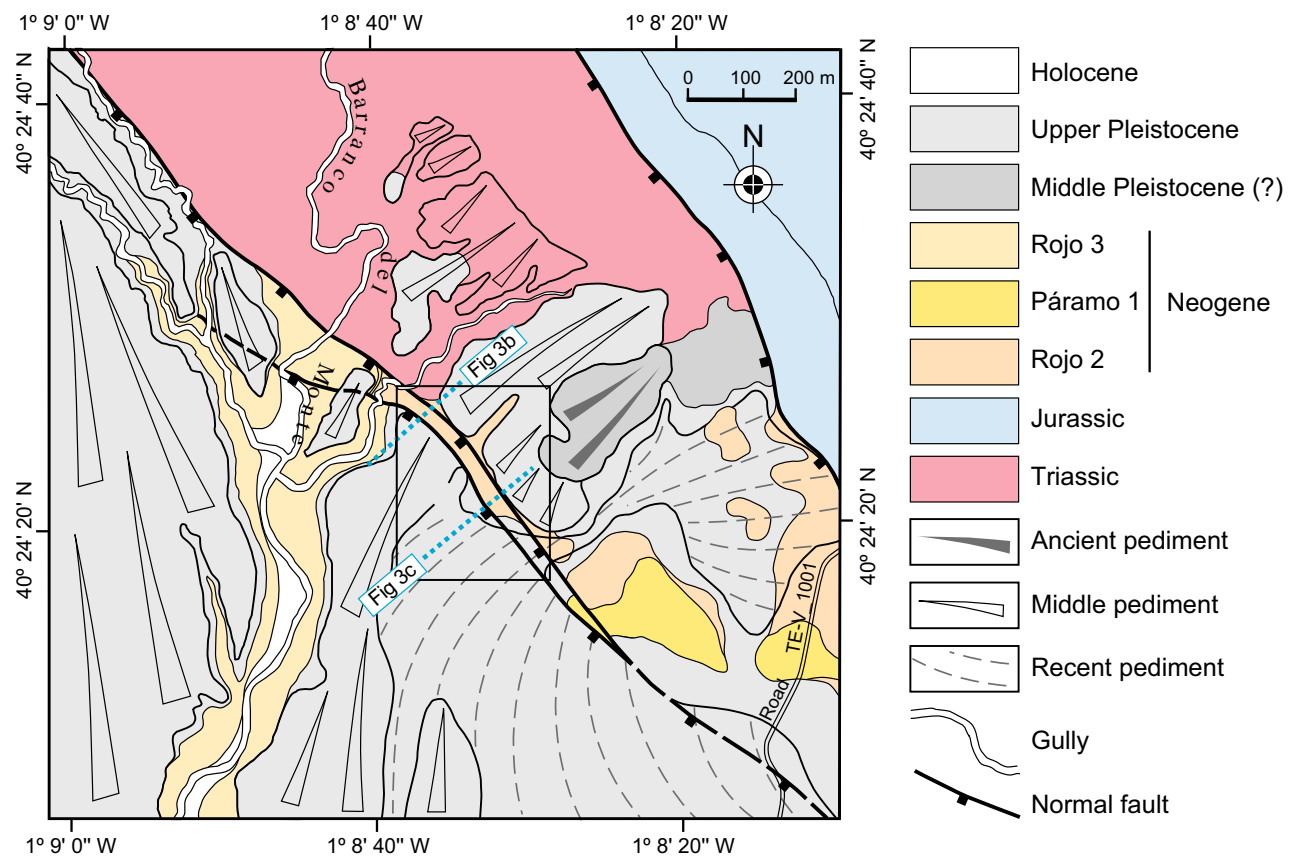

Fig. 2 Detailed geological-geomorphological map of the studied zone. Rectangle indicates the location of the El Hocino area. See Fig. 1 for map location. Blue dotted lines indicate the location of fault exposure (Fig. 3b) and topographic profile (Fig. 3c)

Powell (1873) and McCalpin (2005), grading laterally from a simple high-angle normal fault to synthetic step faults or monoclines. Dips measured at fault surfaces usually range from 65 to $70^{\circ} \mathrm{SW}$, and striations observed at several good exposures indicate a nearly pure normal displacement, with pitch angles ranging from $88^{\circ} \mathrm{NW}$ to $58^{\circ} \mathrm{SE}$. Field survey and mapping along the Concud Fault suggest that it is a non-segmented structure (Lafuente et al. 2011).

The Concud Fault has been active during the Late Pliocene and Quaternary. The pre-tectonic surface above the footwall block forms a structural plain at $1180-1200 \mathrm{~m}$ a.s.l. and is dated at 3.6 Ma (latest Ruscinian; Godoy et al. 1983a; Opdyke et al. 1997; Alcalá et al. 2000). On the hanging-wall block, the surface is at 920-940 m a.s.l., and in some outcrops close to the fault, it is unconformably overlain by the Upper Pliocene and Pleistocene red clastic sediments of the Jiloca graben. This indicates a minimum post-Early Pliocene vertical offset of about $240 \mathrm{~m}$. Considering an average dip of $70^{\circ}$ and pure normal movement, these observations indicate a minimum displacement of $255 \mathrm{~m}$ and a slip rate of $0.07 \mathrm{~mm} /$ year over the last 3.6 Ma. At a trench site $3 \mathrm{~km}$ north of Teruel, a Middle Pleistocene slip rate of $0.23-0.33 \mathrm{~mm} /$ year was estimated (Lafuente et al. 2011) based on a tufa age from the Middle Terraces of the Alfambra River on the footwall block dated between $169 \pm 10$ and $116 \pm 4 \mathrm{ka}$ (Arlegui et al. 2005), and a minimum net displacement of $39 \mathrm{~m}$.

Based on fault length $(14.2 \mathrm{~km})$ and its lack of segmentation at the surface, Lafuente et al. (2011) used several empirical relations (Wells and Coppersmith 1994, Stirling et al. 2002; and Pavlides and Caputo 2004) to estimate the moment magnitude of the maximum expected earthquake $(\mathrm{Mw})$ and its associated coseismic displacement. Magnitudes estimated from different empirical correlation models range from $\mathrm{M}_{\mathrm{w}}=6.4$ to $\mathrm{M}_{\mathrm{w}}=6.8$, with coseismic displacement ranging from 0.35 to $2.02 \mathrm{~m}$ (Lafuente et al. 2011). By applying the original equation by Hanks and Kanamori (1979), Ezquerro et al. (2015) calculate an Mw range from 6.5 to 6.6 .

The estimated magnitudes are consistent with the occurrence of soft-sediment deformation structures within syntectonic units including the Pliocene lacustrine sediments at the hanging-wall block of the Concud Fault (Ezquerro et al. 2015) and Pleistocene fluvial deposits in the vicinity of the fault (Lafuente et al. 2008).

Several paleoseismic studies in trenches along the Concud Fault have been conducted mainly by our team (Lafuente et al. 2011, 2012, 2014; Simón et al. 2012, 2015; Ezquerro et al. 2015), but also for other research groups (Gutiérrez et al. 2008). These studies have characterized the paleoseismic history of the fault, which includes eleven paleo-events since ca. $74 \mathrm{ka} \mathrm{BP}$, with an average recurrence interval between $7.1 \pm 3.5$ and $8.0 \pm 3.3 \mathrm{ka}$. The total net slip during this time lapse is about $20.5 \mathrm{~m}$, resulting in an average coseismic displacement of $1.9 \mathrm{~m}$. The displacement pattern shows alternating periods of fast slip (up to $0.53 \mathrm{~mm} / \mathrm{a})$ and slow slip $(0.13 \mathrm{~mm} / \mathrm{a})$, resulting in average slip rate of $0.29 \mathrm{~mm} / \mathrm{a}$. 
Fig. 3 a and b Photograph and geological cross section of the Barranco del Monte gully (see location in Fig. 2). The step in the glacis surface can be observed, as well as the two normal faults that comprise the southwestern trace of the Concud Fault. c Topographic profile perpendicular to the topographic step including the apparent displacement measurement of the glacis surface (see Fig. 2)

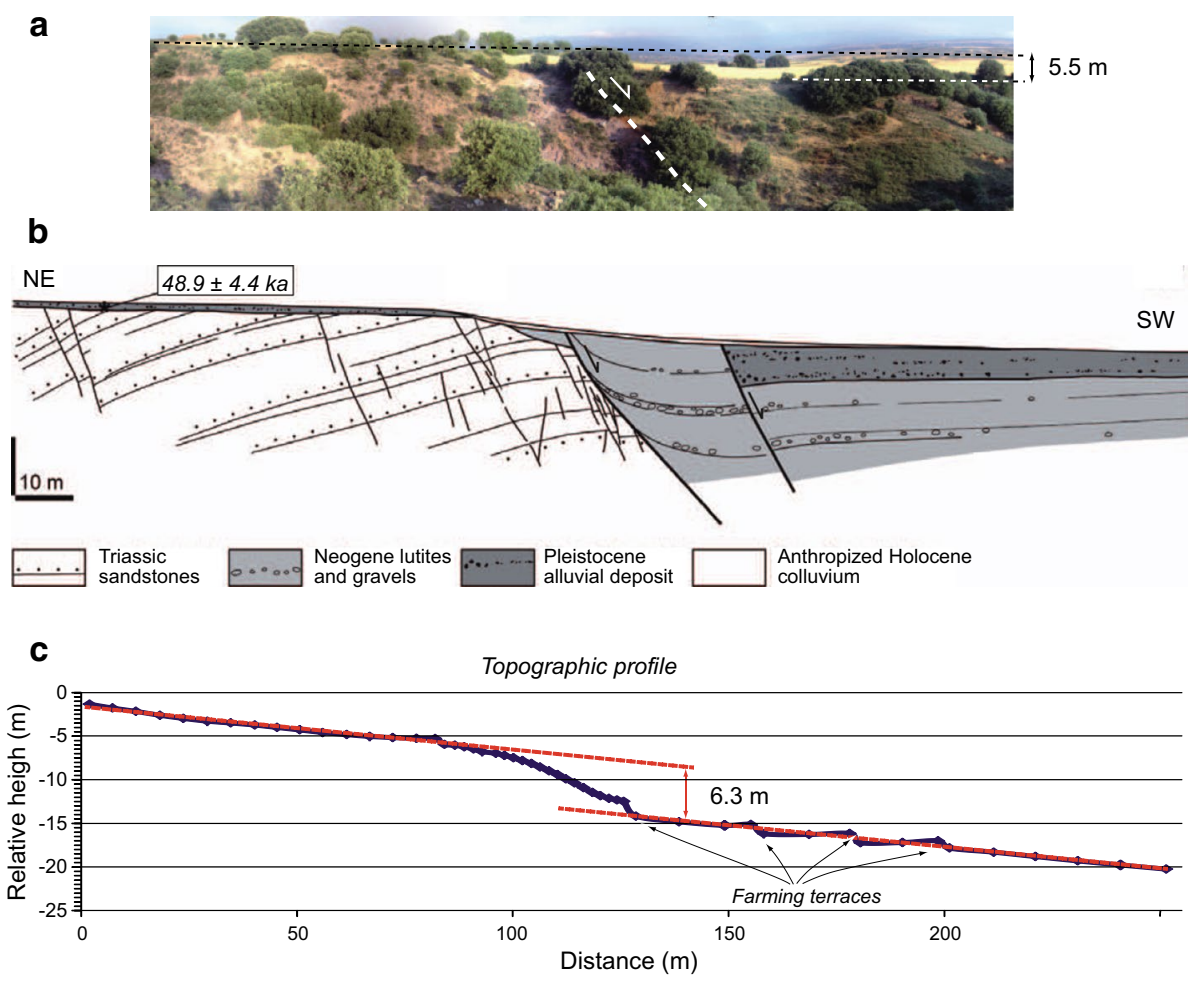

The paleoseismic events identified in our previous studies contrast with the historic and instrumental seismic record of the Iberian Chain, which is characterized by low-moderate seismicity in this area (maximum instrumental $\mathrm{Mb}=4.4$ in Casas Bajas, 2006; IGN 2010). The loci of epicenters are reasonably well correlated with known Neogene-Quaternary faults (Simón et al. 2012; Lafuente et al. 2014) and define the basin bounding extensional macrostructures. The ages of paleoseismic events along the Concud Fault indicate that the fault is characterized by long recurrence intervals typical of intraplate regions (e.g., Lafuente et al. 2014).

In the context of our paleoseismological research, we conducted geophysical surveys along the central part of the fault, previous to excavation of two trenches (see results in Lafuente et al. 2014). In this location, the Concud Fault is divided into two main fault traces, (Fig. 2). At the El Hocino site, the fault splits into at least two fault traces, the southwestern trace being exposed in a natural outcrop at the Barranco del Monte gully (Fig. 3a, b). The main, northeastern trace separates Triassic sandstones from Neogene red gravels, sands, silts and clays that are deformed by decameter-scale drag folding (Fig. 3b). Within the hanging-wall block, the Neogene stratigraphic section is cut by the southwestern fault branch, juxtaposing these sediments against Pleistocene alluvial deposits. Pleistocene alluvial pediment deposits unconformably overlie both Triassic sandstones and Neogene clastics. These pediment deposits have a thickness of ca. $1.5 \mathrm{~m}$ in the footwall and up to
$7 \mathrm{~m}$ in the hanging wall. The age of the pediment surface has been estimated at $48.9 \pm 4.4 \mathrm{ka}$ based on OSL dating, although the reliability of this age is suspect due to agricultural labors (Lafuente et al. 2014).

Along the southern trace, the glacis surface has a linear and clear topographic step nearly parallel to the fault scarp (Fig. 3c), suggesting fault activity subsequent to the piedmont formation. Several topographic profiles across the step suggest that this surface is offset between 5.0 and $6.3 \mathrm{~m}$ (Fig. 3). These profiles, together with our geophysical surveys, were used to select the optimal location for the paleoseismological trenches (Lafuente et al. 2014).

\section{Geophysical survey}

\section{Survey methods, procedures and data processing}

The geophysical survey consisted of three different methodologies, including magnetometry, electromagnetic (EM) multifrequency survey and ground penetrating radar (GPR), undertaken within a farming area east of a gully where the fault is exposed (Fig. 4). The survey covered an area of $30,000 \mathrm{~m}^{2}$.

The magnetometry investigation consisted in the measurement of magnetic field intensity and vertical magnetic gradient (Fig. 4a), which were conducted using an Overhauser effect magnetometer (GSM-19 with two sensors separated $0.5 \mathrm{~m}$ ) as rover with an integrated GPS. Natural 


\section{a Magnetometry survey}

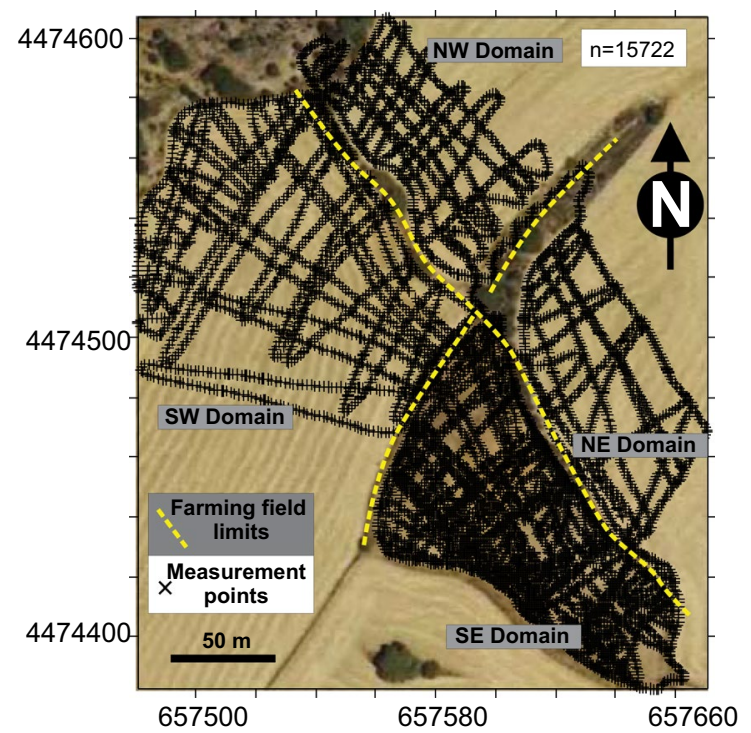

c GPR zones

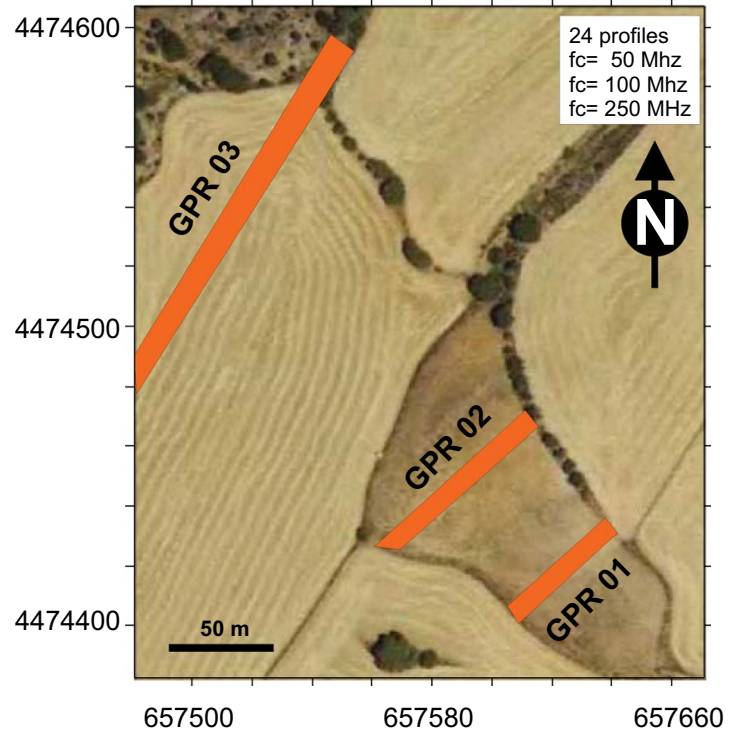

Fig. 4 Investigated area (see Fig. 2) and location of the geophysical observations: a measurement points for magnetometry and distinguished domains during survey; b location of EM multifrequency

variations and diurnal correction were controlled by a precession magnetometer PMG-01 base station. Natural magnetic field changes were corrected to rover data from the base magnetometer. After diurnal correction, the residual anomalies were calculated from the mean magnetic field intensity in order to locate relative changes of magnetic field intensity. Residual magnetic field and vertical gradient data were then plotted into maps of magnetic field changes for the surveyed area. A detailed topographic map was also

\section{b EM profiles}

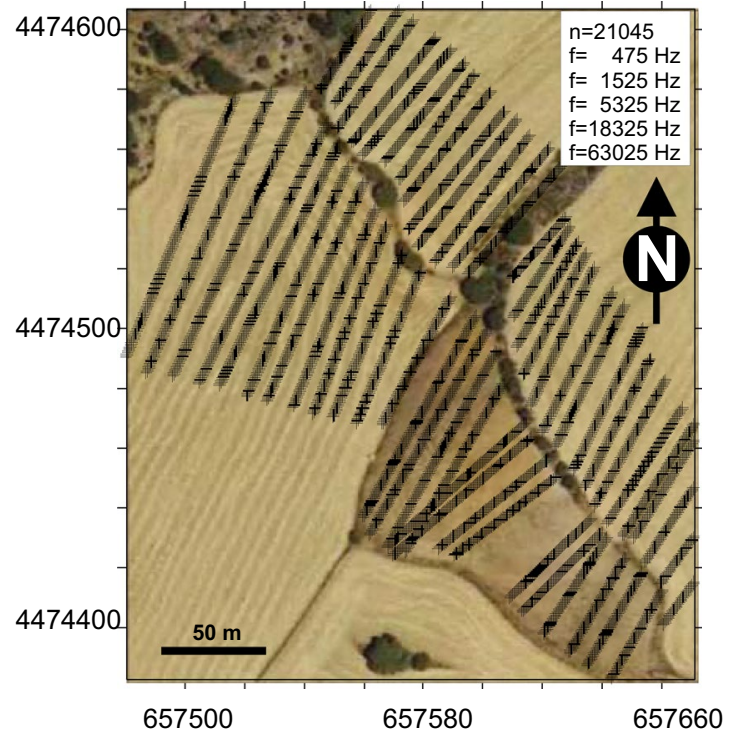

d Topography

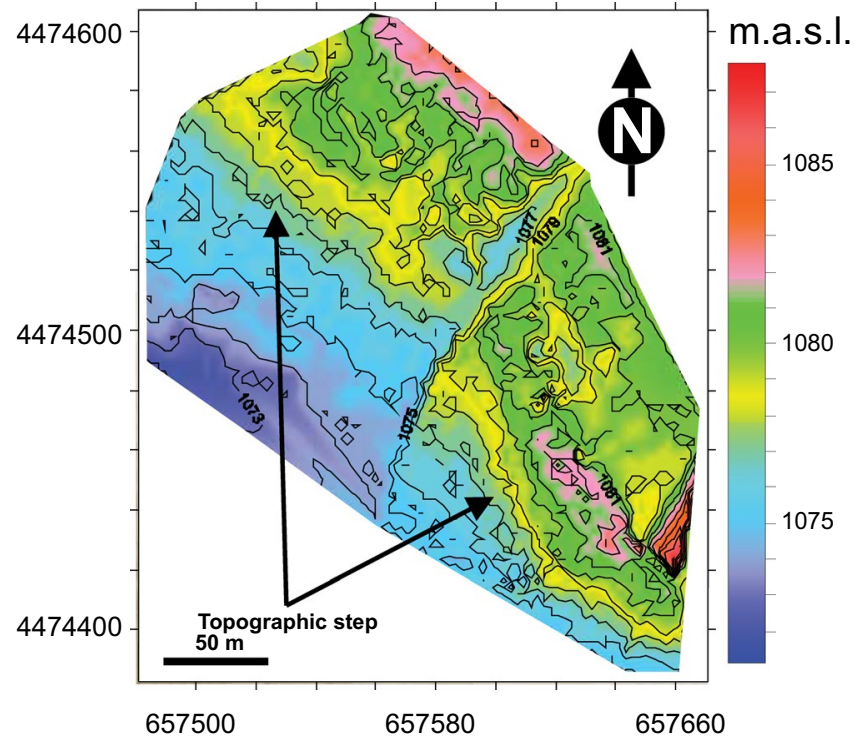

profiles; c location of GPR profiles; and $\mathbf{d}$ topographic map from GPS readings obtained during the geophysical survey

generated based on the elevation data surveyed by the GPS integrated in the magnetometer (Fig. 4d).

The EM multifrequency survey was conducted with a GEM-02 device, along multiple traverses (profiles) across the projection of the fault and covering the same area as the magnetometry survey (Fig. 4b). The survey was performed to evaluate the electromagnetic signal for a range of frequencies between 65 and $0.5 \mathrm{kHz}$, and frequency changes are related to variation of depth analysis intervals (the 
higher the frequency, the lower the analyzed depth interval; Huang 2005). The resulting data represent the measurement of wave in phase and quadrature, which would allow to calculate apparent conductivity and susceptibility values for subsurface materials (Huang and Won 2000). The results were used to generate maps of apparent electrical conductivity and magnetic susceptibility for each frequency based on correlation between measurement points.

The GPR survey was conducted for further characterization of the anomalies identified in the magnetometry and EM surveys. We performed three profiles across the fault close to perpendicular to the anomalies inferred from other geophysical methods. Profiling was conducted using different central frequency antennas of 50,100 and $250 \mathrm{MHz}$ from Ramac (Fig. 4c), with the goal of obtaining different resolution and potential penetration depth; the $50-\mathrm{MHz}$ antenna was unshielded, while the $100-$ and $250-\mathrm{MHz}$ antennas were shielded. Each profile was surveyed twice with different configurations (depth analysis changes), with unshielded antennas disposed parallel and transverse to the survey direction (PL-BD and PR-BD, respectively; after Annan 2004). This approach enhances subsoil changes and increases the sensitivity of the antennas for identifying structures normal to the survey direction (e.g., the fault planes). Shielded antennas of 100 and $250 \mathrm{MHz}$ were moved only in PR-BD configuration.

GPR profiles were surveyed through trigger interval over the spatial resolution of the antennas to avoid significant resolution decreases during processing. Data processing consisted in signal increase with depth (linear and exponential gain), filter frequencies out of range, and for cases where non-homogeneous displacement of the devices was carried out, running average routines were performed. The dielectric constant calculations were performed by fitting hyperbolic anomalies to obtain the propagation velocity and propagation velocities of GPR waves in the surveyed materials ranged from 77 to $89 \mathrm{~m} / \mathrm{s}$. These values were applied for the profile migration, establishing the correlation between depth and two-way travel time (TWT) intervals; setting intervals were configured, after a preliminary test, at 15,7 and $3 \mathrm{~m}$ for $50-, 100-$ and $250-\mathrm{MHz}$ antennas, respectively. GPR profiles were examined to identify lateral changes in geometry, apparent EM variations, and lateral interruptions of the horizontal banded disposition at GPR profiles.

\section{Results of magnetometry}

The magnetometry survey extended across farming terraces along several topographic steps (see Fig. 4a, d). Along the farming field boundaries, accumulation of rocks originated from scouring fields farming typically yields sharp topographic steps between fields and conditions subsequent ground levelling. In this manner, to avoid the potential influence of these anthropogenic modifications, our surveys did not include the edges of the farming fields. The topographic map (Fig. 4d) indicates slope changes related to the farming field boundaries, as well as a small slope inflection trending NW-SE. The slope inflection is parallel to the Concud Fault and is likely to represent the trace of the fault and a subdued expression of past surface ruptures. Several observations can be made on the distribution of the anomalies that modify the general trend of geophysical properties (for their spatial distribution see Fig. 4a).

Magnetic maps regarding vertical magnetic gradient (Fig. 5a) and residual magnetic field (Fig. 5b) show three main groups of anomalies ( $\mathrm{G}$ and $\mathrm{M}$, respectively) that are consistent. Northeast of the fault, anomalies G1 and M1 have an orientation of SSW and correlate with a small gully that divides both northeastern farm fields. In this area, we find the highest vertical gradient values and lower residual magnetic field values. Anomaly G2 has a general NW-SE orientation, crosses different farm fields with a small magnetic inverse dipole lineation (negative-positive from $\mathrm{S}$ to $\mathrm{N}$; inverse dipole) and shows a continuous decrease in magnetic field value from SW to NE until it sharply increases in the central zone of the surveyed area. This anomaly is independent of farming limits, and it is parallel to the topographic slope inflection. After converging into a continuous lineation, anomalies G2 and M2 exhibit a slight change in orientation (labeled as $\mathrm{G} 2^{\prime}$ and $\mathrm{M} 2^{\prime}$ ). To the south of the $\mathrm{G} 2$ and M2 anomalies, another inverse dipole lineation trending NW-SE defines anomalies G3 and M3 that only extend across the eastern end of the survey and to the southwest of $\mathrm{G} 2^{\prime}$ and $\mathrm{M} 2^{\prime}$ anomalies.

\section{Results of electromagnetic multifrequency survey}

Apparent susceptibility maps drawn from the EM results for each frequency showed similar distributions, and therefore, only the map obtained from a $63,025 \mathrm{~Hz}$ frequency is shown (Fig. 6a). This map includes a NW-SE trending band of lower apparent susceptibility that extends across the entire survey (anomaly EM1). This anomaly is spatially coincident with the G2-G3 and M2-M3 anomalies identified in the magnetometry surveys and also parallel to the topographic slope escarpment, irrespective of farming field boundaries. Although it appears at all frequencies, this anomaly is better defined at the highest measurement frequencies.

An anomaly is also clearly identifiable in the apparent conductivity maps for different frequencies (Fig. 6b-d). This anomaly is spatially coincident with the map trace of anomaly EM1, and associated with a persistent contrast of more than $25 \mathrm{mS} / \mathrm{m}$ that can be followed along low-frequency measurement (up to 20-25 m deep), although the 


\section{a Vertical magnetic gradient}

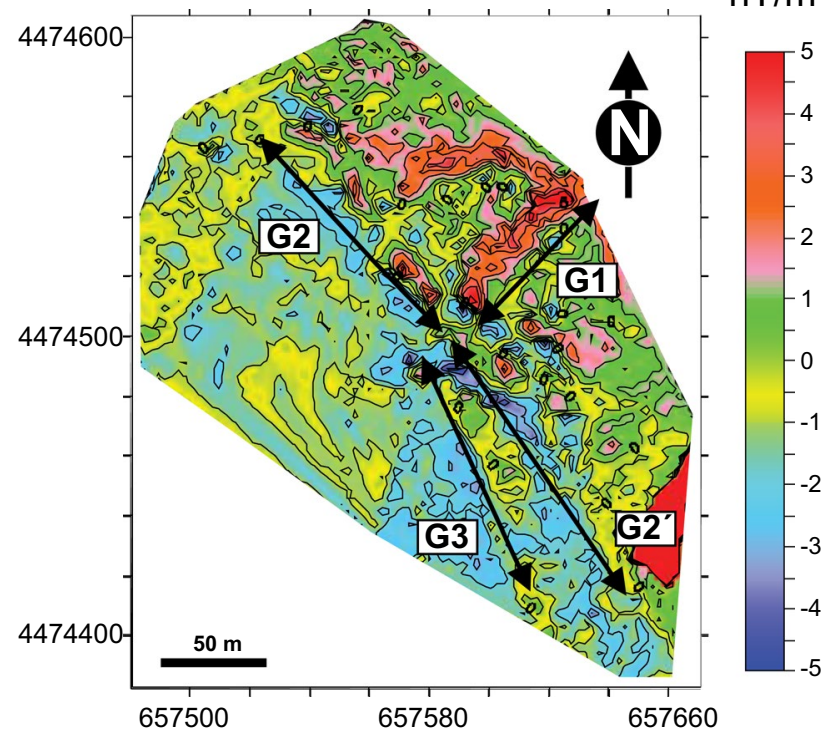

b Residual magnetic field

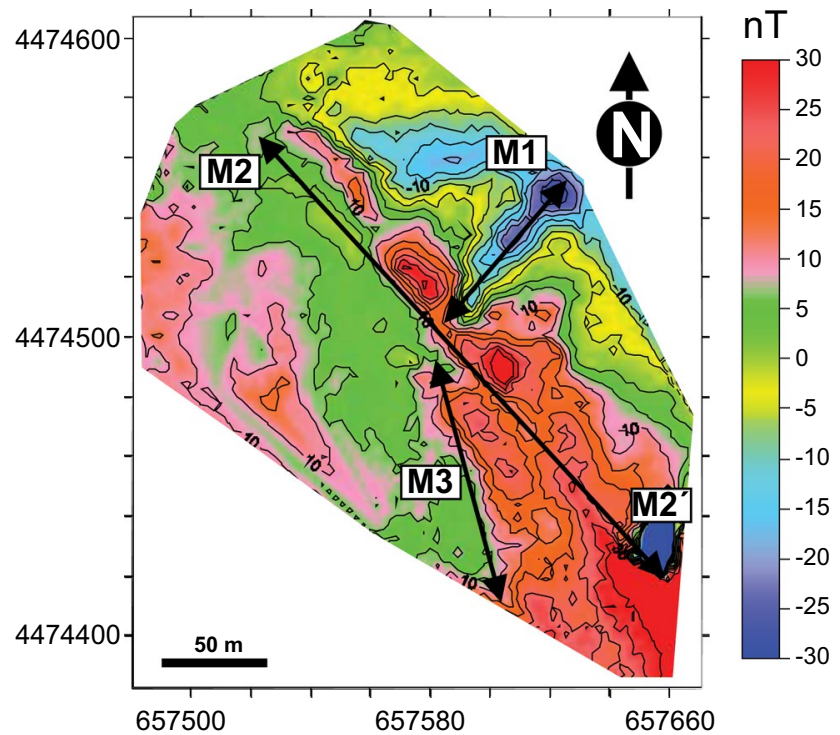

Fig. 5 Results of magnetometry survey: a vertical magnetic gradient map, with the location of the main anomalies (G1, G2-G2' and G3) and b residual anomalies map from intensity of the Earth magnetic field, and main anomalies (M1, M2-M2' and M3)

contrast between the anomaly and the surrounding conductivity values decreases with depth. The conductivity anomalies are also coincident with the topographic escarpment.

\section{Results of Ground Penetrating Radar}

In general, GPR profiles 1, 2 and 3 (Fig. 4c) show homogeneous, nearly horizontal reflectors that are locally cut by clusters of anomalies, lateral continuity variations, offsets, dip changes and other geometrical changes between reflectors (Figs. 7, 8).

In the 40-m-long profile GPR 01, anomalous features are observed between about 15-35 m. (Fig. 7), and the expression of these features varies on the depth plots depending on frequency, device configuration and migration/non migration of profile data (Fig. 7a-d). In low-frequency $(50 \mathrm{MHz})$ unmigrated and migrated profiles, we observe net lateral changes at medium to deep levels, and changes in reflectors dip at shallower levels (Fig. 7a, b). Clear offsets are observed between 16 and $22 \mathrm{~m}$ and to a lesser extent between 28 and $34 \mathrm{~m}$. Reflectors are associated with changes in dip, rollover and drag folding, adjacent to the offsets. Among them, a significant rollover monocline, better exhibited at the PR-BD configuration (Fig. 7b), appears between meters 10 and 22 (horizontal scale), where NE-dipping reflectors are truncated against relatively flat reflectors. Shallower reflectors that on-lap the monocline to the NE show a wedge shape open to the NE. The uppermost reflectors ( $>2 \mathrm{~m}$ deep) are not disturbed. High-frequency GPR profiles show a more complex set of reflectors (Fig. 7c, d). In both the 100- and $250-\mathrm{MHz}$ profiles, general northeast-dipping reflectors are observed from about 5-20 $\mathrm{m}$ and appear to be truncated by an anomaly that does not reach the surface. In migrated profiles and 50-MHz profiles (Fig. 7), this zone shows a lateral, nearly vertical interruption of the stratigraphy. From these observations, we infer the presence of: (1) a SW-dipping fault located at distance $22 \mathrm{~m}$ in the profile, which produced the tilting and rollover geometry of deeper reflectors; (2) the wedge-shaped geometry of shallow reflectors is related to syn-tectonic deposition (Fig. 8a); and (3) the flat-lying geometry and continuity of the shallowest reflectors indicates a period of tectonic quiescence in which the fault was buried.

Profile GPR 02, $40 \mathrm{~m}$ in length, shows similar features (Fig. 8b). An offset of reflectors occurs at a distance of $27 \mathrm{~m}$ in the profile. This discontinuity has a dip toward the SW and separates relatively flat-lying reflectors NE of the discontinuity from northeast-dipping reflectors (between $7 \mathrm{~m}$ and the discontinuity) that define a rollover monocline southwest of the discontinuity. Within the rollover monocline, minor synthetic and antithetic discontinuities, located between 18 and $24 \mathrm{~m}$, are associated with clear offsets and drag folds, and the uppermost reflectors show a wedge-shaped geometry open toward the major discontinuity. These features may be interpreted in the same way as described for profile GPR 01.

Profile GPR 03, $250 \mathrm{~m}$ in length, shows relatively flat-lying reflectors across the entire profile (Fig. 8c). Stratigraphic reflectors are offset, bent or warped across 
a Apparent susceptibility $(\mathrm{f}=63025 \mathrm{~Hz})$

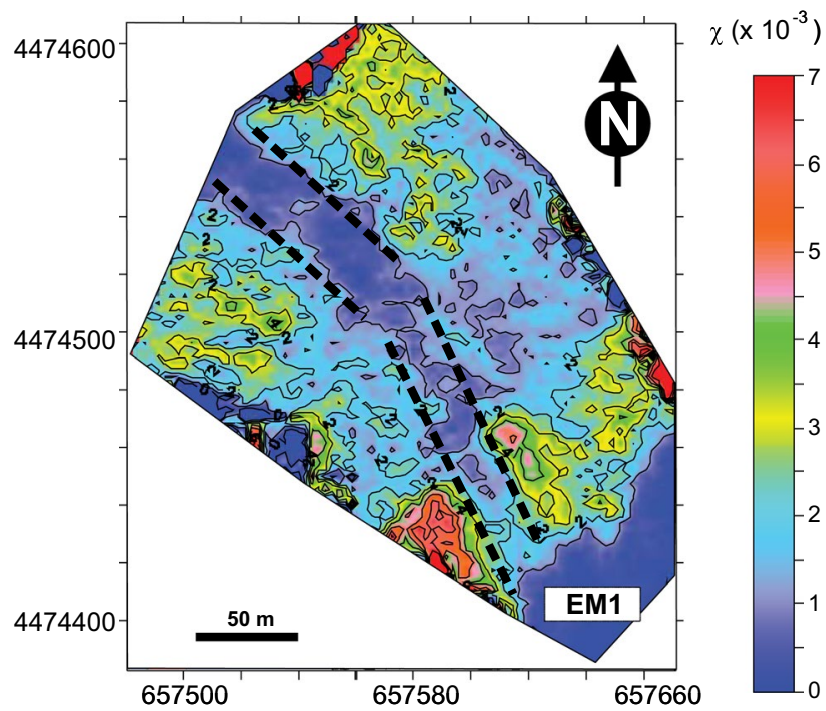

c Apparent conductivity $(\mathrm{f}=5325 \mathrm{~Hz})$

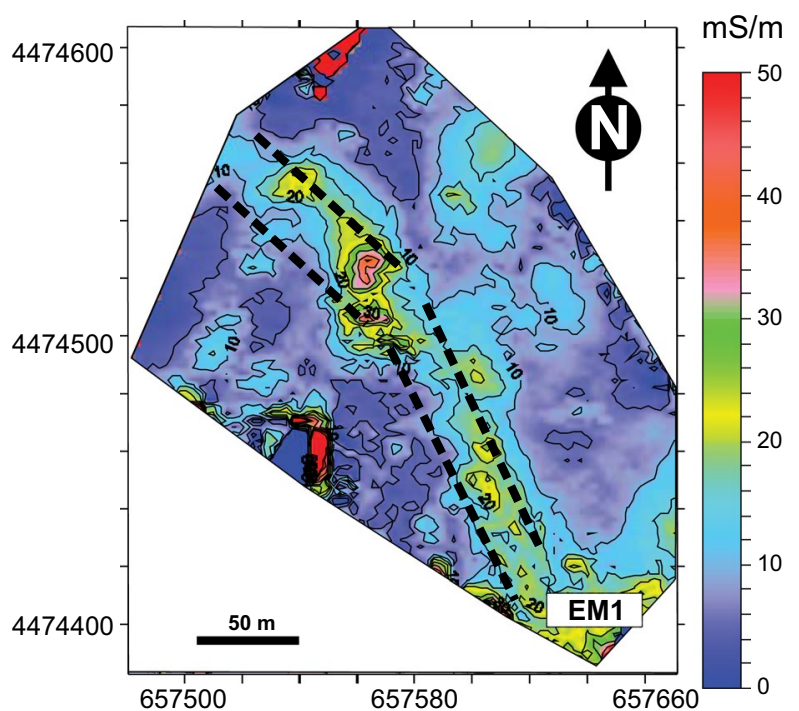

b Apparent conductivity $(\mathrm{f}=63025 \mathrm{~Hz})$

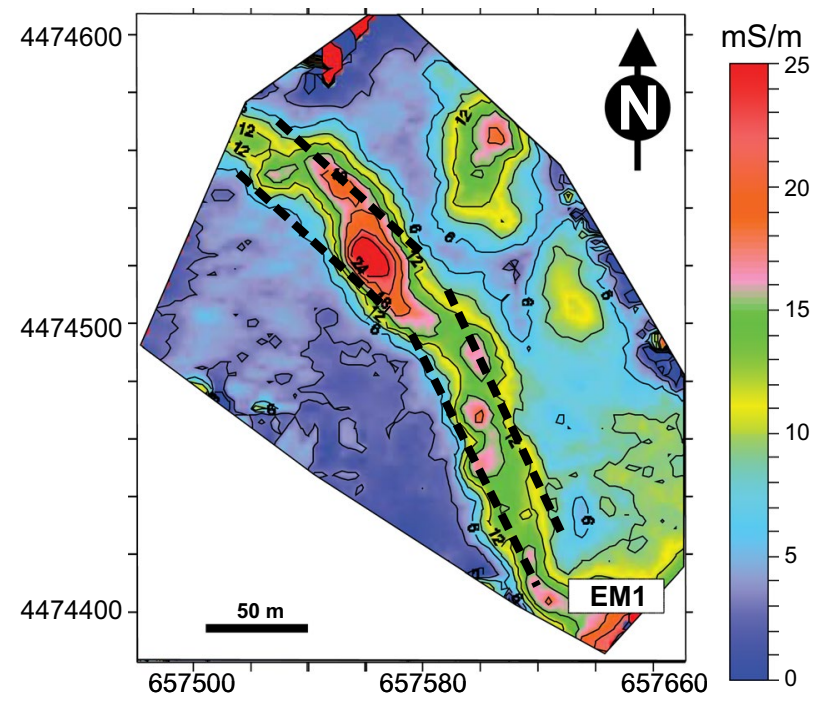

d Apparent conductivity $(\mathrm{f}=18325 \mathrm{~Hz})$

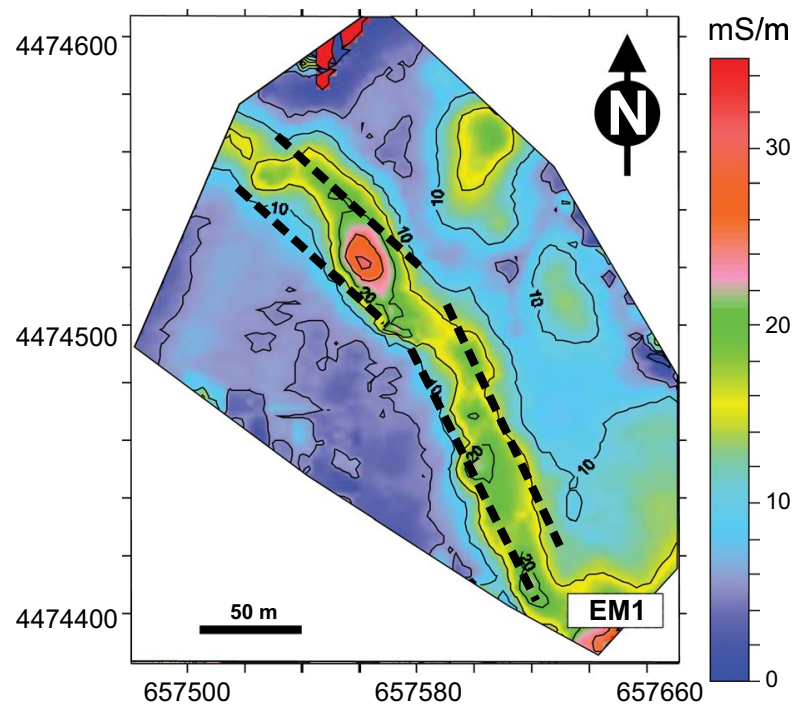

Fig. 6 EM survey results: a apparent susceptibility map obtained for the shallowest frequency $(65,325 \mathrm{~Hz})$. b, c and d Apparent conductivity maps for frequencies $63,025,5325$ and $18,325 \mathrm{~Hz}$, respectively

discontinuities at 50 and $200-250 \mathrm{~m}$ consistent with tectonic displacement across faults associated with minor antithetic and synthetic faults.

\section{Integration of geophysical results}

Magnetometry, electromagnetic and GPR surveys showed anomalies that are consistent and that can be correlated across the entire study area. Several anomalies correlate with surface features, such as rows of trees or farm field boundaries. A prominent NW-SE trending geophysical anomaly (G2, M2, EM1 and GPR dislocations) is observed by all geophysical methods and parallels a subtle topographic slope inflection across the farm fields. This NWSE lineation is coincident with the location of the southern trace of the Concud Fault (Fig. 2).

To evaluate this prominent NW-SE lineation in detail, we correlated the electromagnetic and magnetic results with the GPR profile 03 and this comparison highlighted the presence of two clear anomaly clusters (Fig. 9).

The main anomaly is located in the northeastern section of the profile, where a cluster of geophysical anomalies occurs at circa position $220 \mathrm{~m}$. There are expressed as: 


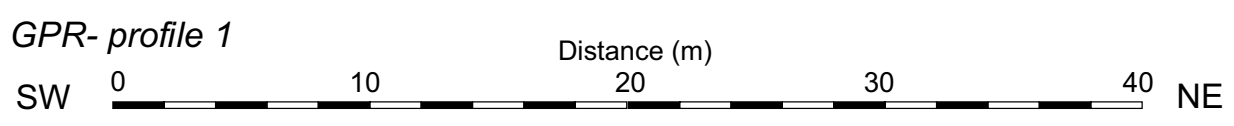

a Unshielded antenna $50 \mathrm{MHz}$ (PL-BD)

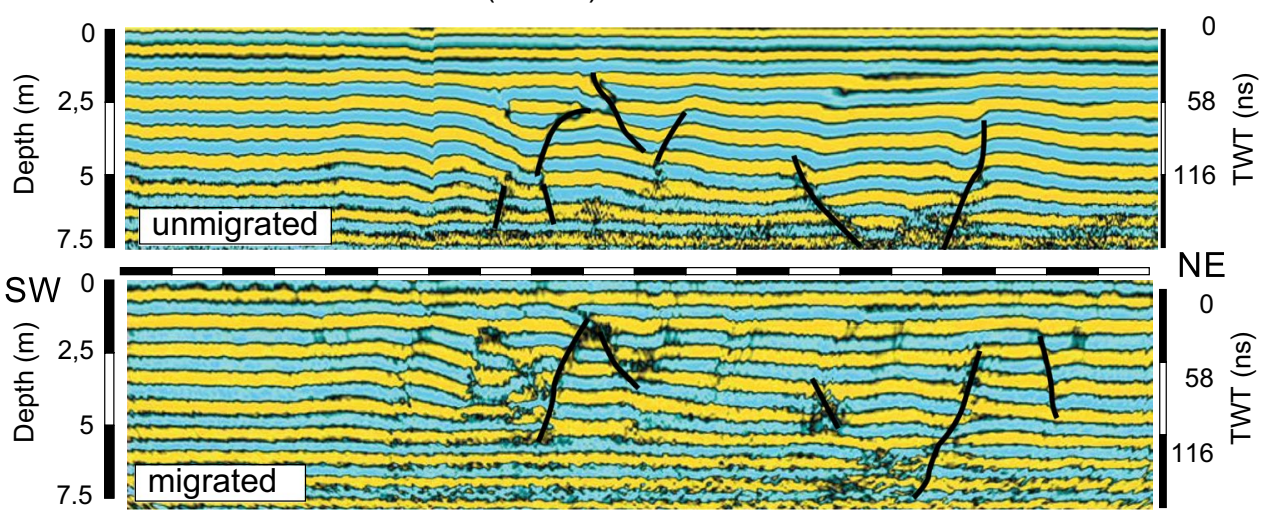

b Unshielded antenna $50 \mathrm{MHz}$ (PR-BD)

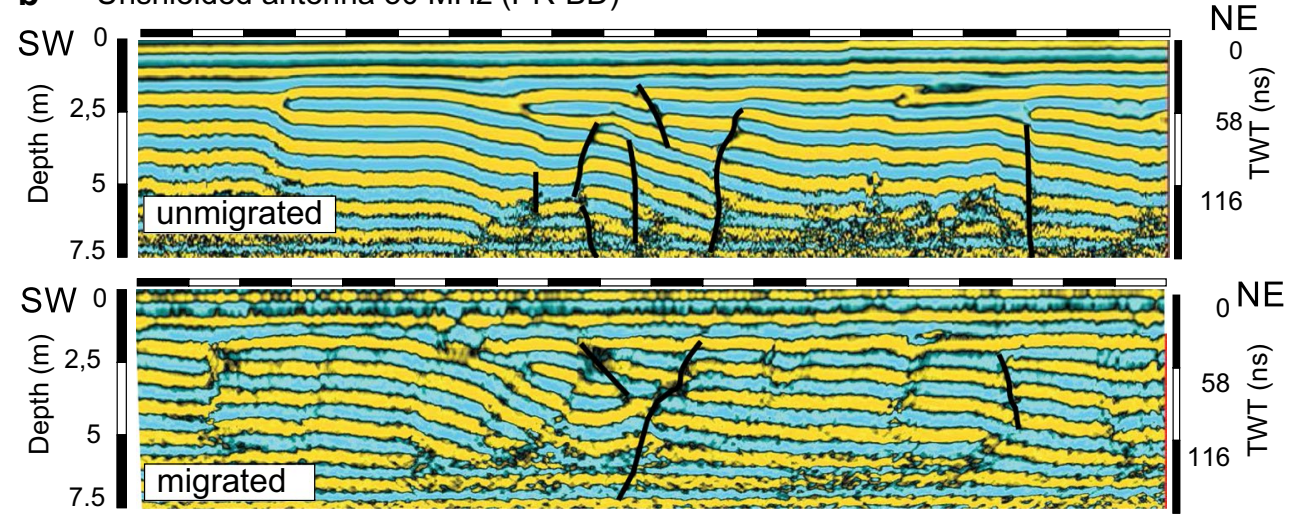

C Shielded antenna $100 \mathrm{MHz}$ (PR-BD)

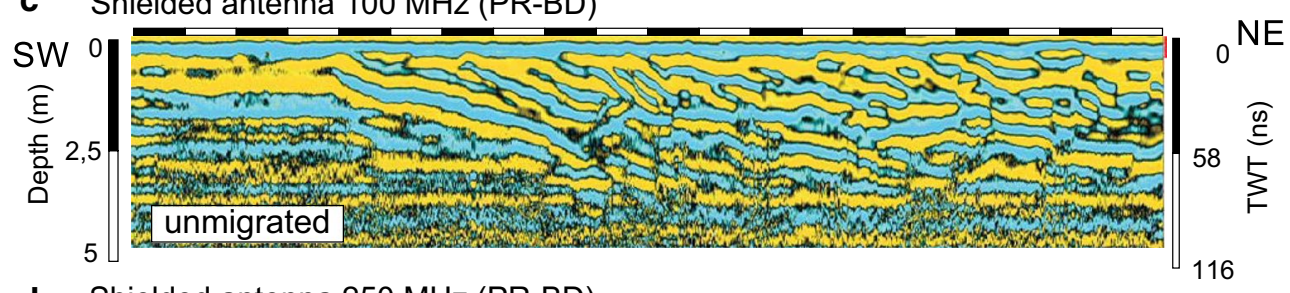

d Shielded antenna $250 \mathrm{MHz}$ (PR-BD)

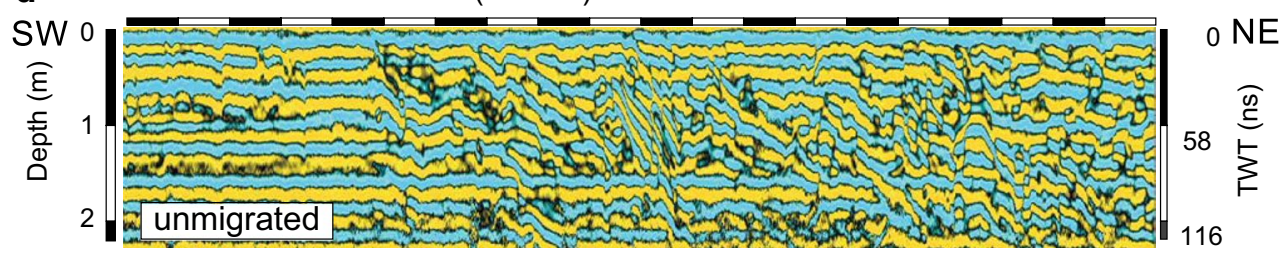

Fig. 7 GPR profiles from section 1 (see Fig. 4c for location): a unmigrated and migrated profile obtained with $50-\mathrm{MHz}$ antennas in PL-BD configuration; b unmigrated and migrated profile in PR-BD

(1) reflector interruptions at the GPR profile near the surface, interpreted as the expression of a major southwestdipping normal fault (Fig. 9a); (2) a sharp increase (from northeast to southwest) in apparent conductivity at position $220 \mathrm{~m}$, better defined at shallower levels (Fig. 9b, c; EM1 configuration for the same transect; c profile with 100-MHz antennas; and $\mathbf{d}$ profile with $250-\mathrm{MHz}$ antennas

anomaly), which maintains higher values toward the SSW for a distance of about $70 \mathrm{~m}$ to around meter 150 on the profile; (3) two magnetic inverse dipoles (the northeastern one being more developed), for both residual anomaly and vertical gradient (G2 and M2 anomalies, Fig. 9d, e, 
Fig. 8 GPR profiles for sections a profile $1(100 \mathrm{MHz})$; b profile $2(50 \mathrm{MHz}$ unmigrated); and c profile $3(50 \mathrm{MHz}$ migrated; see Fig. 4c for location)
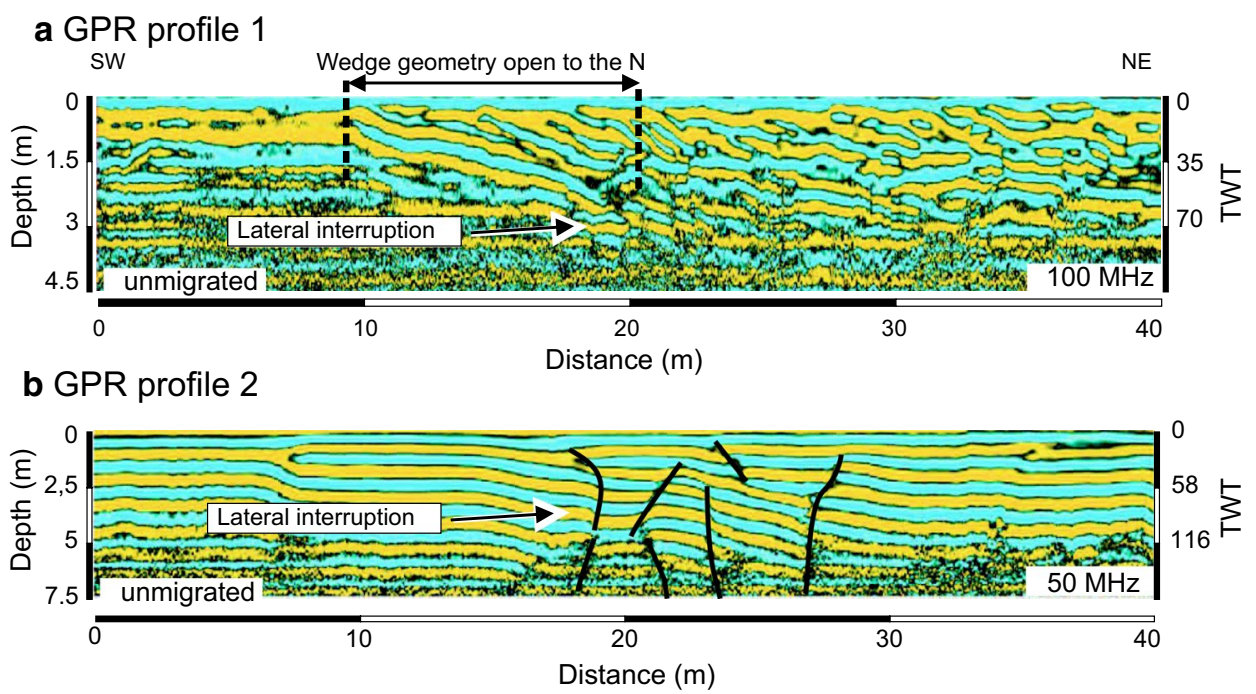

c GPR profile 3

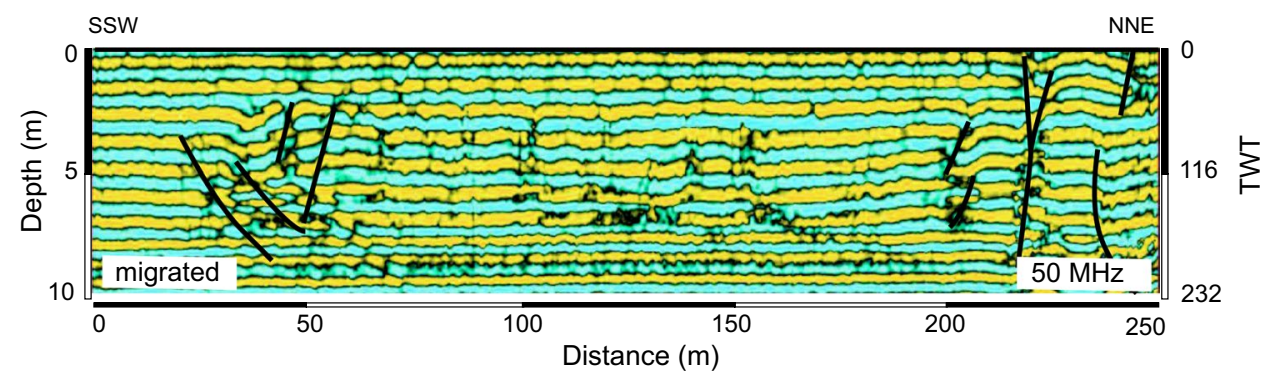

respectively); and (4) a sudden decrease in apparent susceptibility at position $230 \mathrm{~m}$ (Fig. 9f) coincident with the shallowest interruption of GPR reflectors.

A second, southwestern and less prominent cluster of anomalies was recognized around position $50 \mathrm{~m}$ of the profiles. This anomaly is associated with: (1) several lateral interruptions of GPR reflectors (Fig. 9a), interpreted as effects of several minor normal faults (dipping to the north and south) buried by undisturbed reflectors near the surface; (2) a clear increase (from south to north) in the apparent conductivity trend at the $1535 \mathrm{~Hz}$ frequency that disappears at the shallowest levels (18-65 kHz) (Fig. 9b, c); (3) a change in vertical magnetic gradient trend (Fig. 9d); and (4) a small inverse magnetic dipole (Fig. 9e). The results for the southwestern part of the profile show higher anomalies at intermediate to deep intervals, and a lesser variation at shallower levels on the GPR profiles and electromagnetic surveys.

For the remaining profile section, located between the geophysical anomalies, it was recognized a general upwards concave shape in the vertical magnetic gradient curve with small local magnetic dipoles that are parallel to small interruptions in the GPR profiles, local changes of the residual magnetic field trend (that exhibit a general decrease to the northeast), and a transition zone in apparent conductivity (Fig. 9). All these features indicate a generally undisturbed zone between the two geophysical anomalies clusters.

In order to analyze variations between the different frequencies measured in the EM survey, the apparent conductivity and susceptibility for different frequencies are shown in Fig. 9c. If the relative contrasts of apparent conductivity are analyzed through their normalized values, the southwestern anomaly only appears at the $1535 \mathrm{~Hz}$ frequency, in contrast to the northeastern anomaly that peaks at all the frequencies. Within the northeastern anomaly, amplitude decreases at deeper intervals, and it shows a progressive displacement of maxima to the northeast (approaching the fault), as the frequency decreases. This progression means that the highest contrast occurs at the most superficial intervals, likely related to a thicker Quaternary deposit on the hanging-wall block. Additionally, the anomaly gets narrower with depth. In map view, we observe (1) a higher apparent conductivity (EM1 anomaly), (2) a decrease in apparent susceptibility, (3) an increase in the residual magnetic field (M2) surrounded by small magnetic vertical gradient dipoles (G2) and (4) inhomogeneous sectors in GPR profiles (interruption of lateral continuity of subsurface features or geometrical changes within reflectors). These features define a NW-SE trending lineation that can be 
a GPR profile 3. Shielded antenna $50 \mathrm{MHZ}$ (migrated)

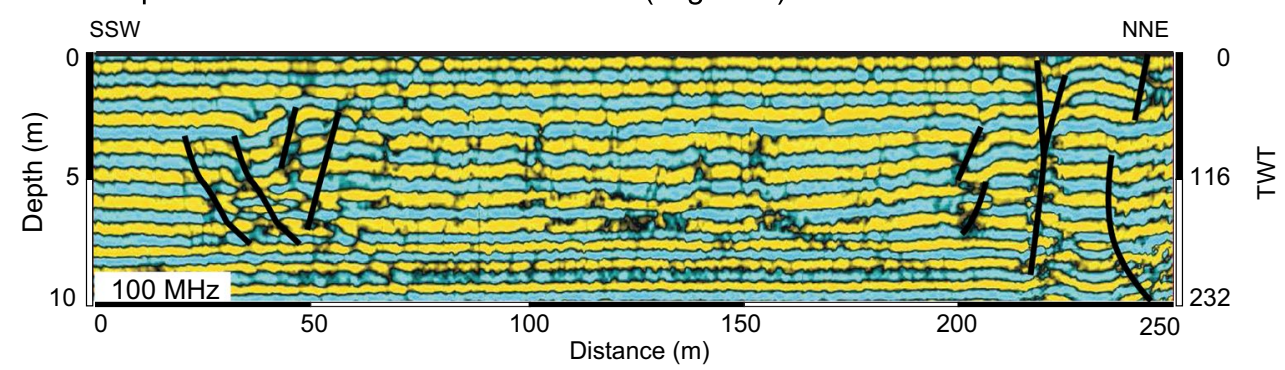

b Apparent conductivity

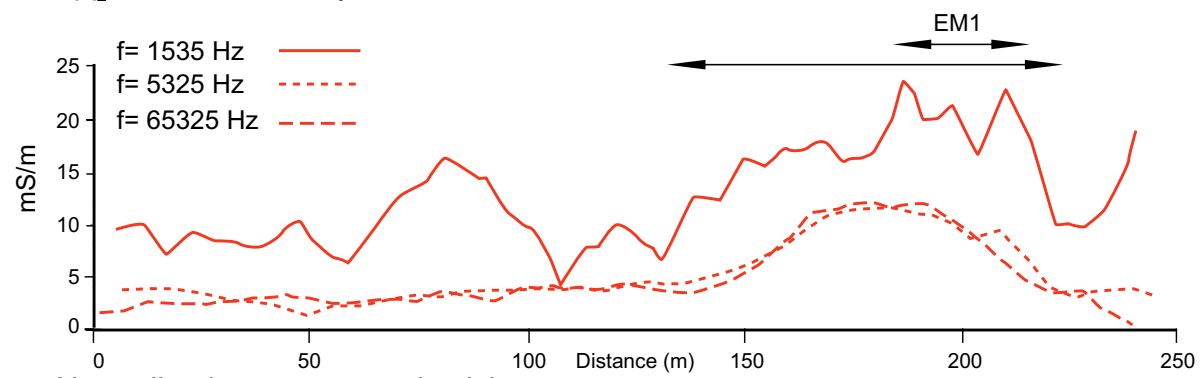

c Normalized apparent conductivity

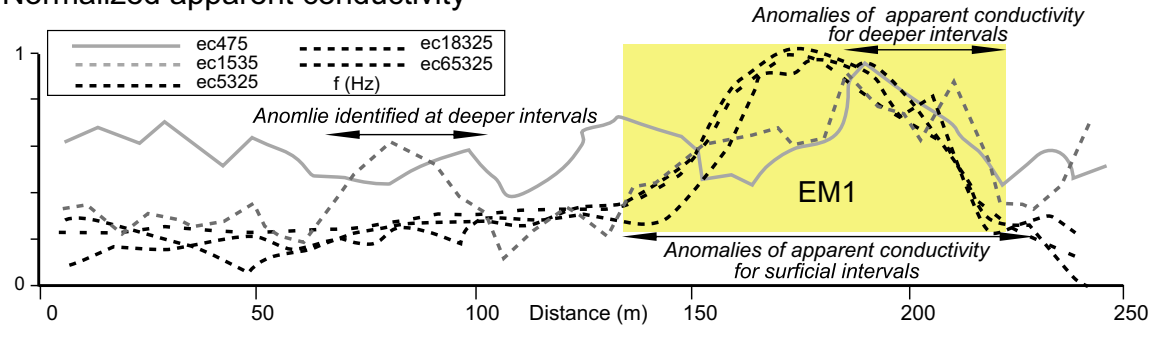

d Vertical magnetic gradient

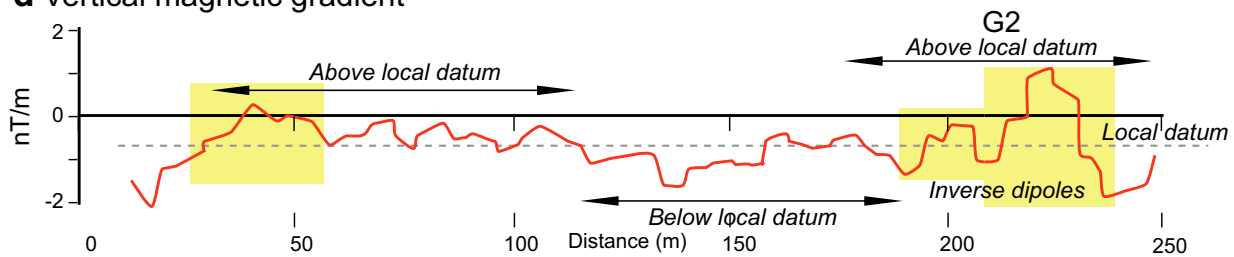

e Residual magnetic anomaly

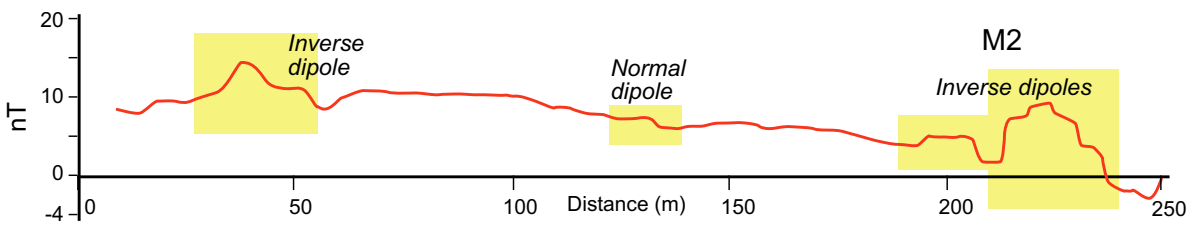

f Apparent susceptibility $(f=65325 \mathrm{~Hz}$ )

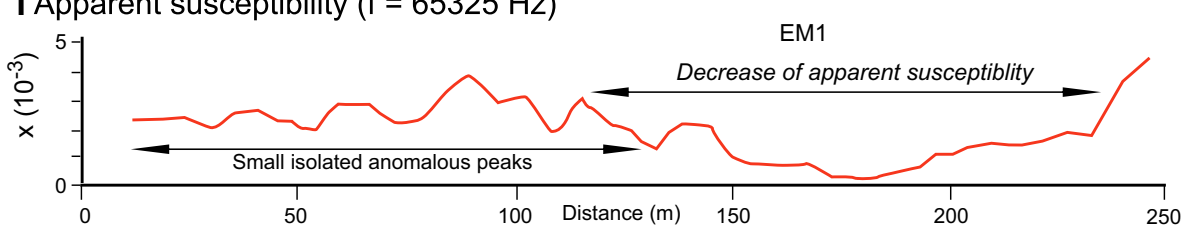

Fig. 9 Detailed analysis for GPR profile 3 (see Fig. 4c for location): a GPR profile, b changes in apparent conductivity, $\mathbf{c}$ superimposed representation of apparent conductivity normalized values for each frequency, $\mathbf{d}$ plot of changes of vertical magnetic gradient, e residual magnetic anomaly and $\mathbf{f}$ apparent susceptibility for superficial frequencies $(f=65325 \mathrm{~Hz})$ 


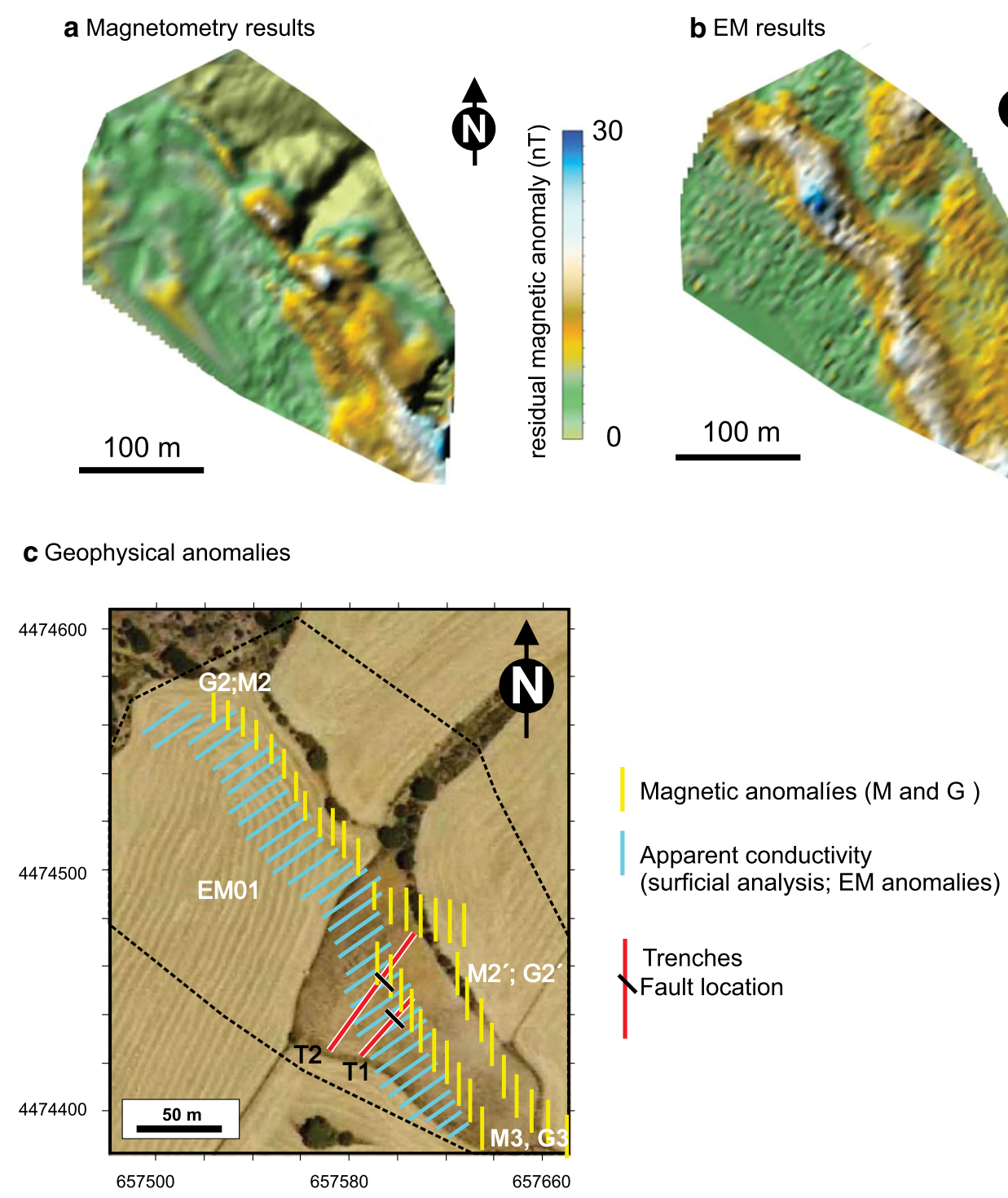

Fig. 10 Geophysical anomalies along the studied zone for the shallowest analyzed interval. a Residual magnetic anomalies map in relief projection obtained from magnetometry. b Apparent conductivity anomalies map in relief projection from EM. c Location of the

main anomalies on the aerial photograph (dotted black lines indicate the survey boundaries). The location of trenches dug to survey both groups of anomalies is also marked

followed through the entire study area (Fig. 10). This linear anomaly is interpreted to be the product of deformation associated with the NW-SE trending, SW-dipping Concud Fault, consistent with the observations in GPR profile 03.

\section{Comparing geophysical results with trench observations}

The combined geophysical results were used to select the location of two paleoseismic trenches (T1 and $\mathrm{T} 2$ ) that were excavated perpendicular to the main lineal geophysical anomalies and the fault trace (Fig. 10). Both trenches

provided similar results, as described by Lafuente et al. (2014). We chose trench T2 to compare with our analysis, and to facilitate a comparison with our geophysical investigation, we will briefly summarize the paleoseismological trenching results (Fig. 11a).

Trench 2 exposed a normal fault trending $\mathrm{N} 163^{\circ} \mathrm{E}$ and dipping $70^{\circ} \mathrm{W}$, with two sets of striae pitching $75^{\circ} \mathrm{S}$ and $53^{\circ} \mathrm{N}$. The footwall block showed fractured Neogene (Upper Turolian) sands and mudstones, and a distributed brittle fault zone associated with discrete rupture planes mostly synthetic with the main fault (Fig. 11a, b). The hanging-wall block showed six Pleistocene detrital sedimentary units (1-6) varying in composition from sand to 


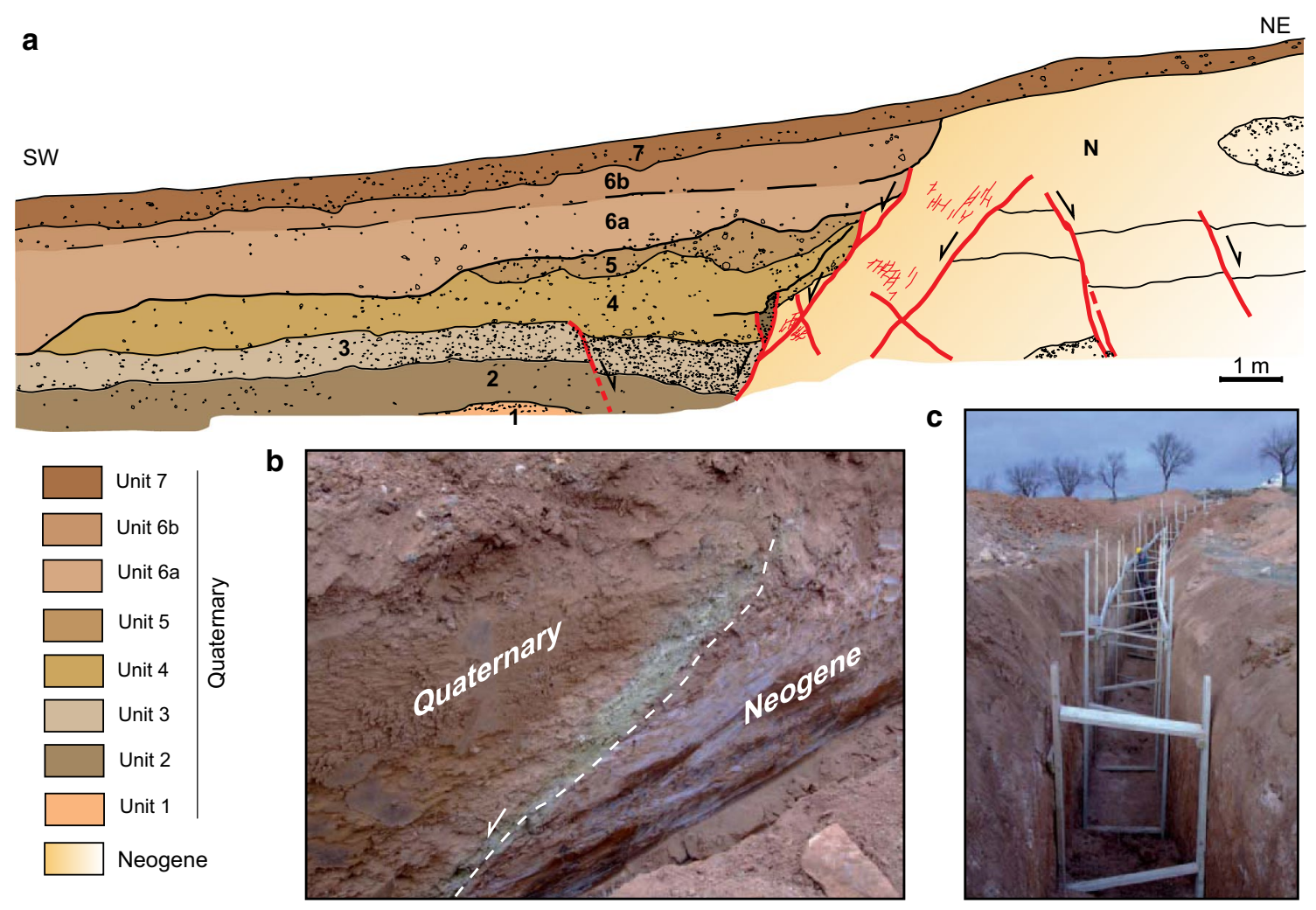

Fig. 11 a Stratigraphic and structural log of the northwestern side of trench 2 (see location in Fig. 10). b Photograph of the fault exposed in the trench. $\mathbf{c}$ Photograph of the trench excavation, view northeast

micro-conglomerate and with variable carbonate percentage (Fig. 11a). Lafuente et al. (2014) interpreted these deposits to be associated with sheet-flood processes or local channel deposition related to the piedmont planation. Several units exhibit a gentle dip and thicken toward the fault, which is interpreted as rollover geometry related to fault activity (Fig. 11a). Erosional surfaces within Quaternary sedimentary deposits enhanced successive episodes of formation, degradation, burial and reactivation of the fault scarp, reflecting seismic and interseismic cycles (Lafuente et al. 2014). An anthropogenic colluvial deposit (unit 7) buries both hanging-wall and footwall materials.

Trench T2 was excavated across anomalies EM1, G3 and M3 (Fig. 10). The location of the normal fault exposed in trench T2 coincides with the G3-M3 magnetic anomalies (Fig. 12a), and close to the electromagnetic anomaly EM1 (Fig. 12b). Both contrast and width of the anomalies decrease with depth, being slightly displaced southeastward from the fault as well. The apparent conductivity anomaly (EM1) is wider near the surface, and it gets narrower and closer to fault plane with depth. The anomalies exhibit the maximum peak in the northeast and extend adjacent to the southwestern side of the fault. Apparent susceptibility shows a general increase to the northeast, with some minor peaks coincident with the fault. The GPR profiles in the vicinity of the trenches (GPR 01 and GPR 02) show a wedge geometry open to the northeast in the $50 \mathrm{MHz}$ (Fig. 12c), a wedge geometry (on-lap) overlapping a net change that produces an hyperbolic anomaly below it in the 100-MHZ profile (Fig. 8a), and an anomalous area in the $250-\mathrm{MHz}$ profiles associated with a subvertically bounded lateral contrast. The GPR profiles obtained using the $50-\mathrm{MHz}$ antenna show the greatest similarity to the stratigraphic observations from trench T2 (Fig. 12d). Thus, the main and minor (antithetic and synthetic) faults, as well as the main geometrical features of the stratigraphic section (rollover folding of lower reflectors, thickening of central reflectors against the main fault, and non-disturbance of upper reflectors) inferred from the GPR profile are consistent with trench observations. However, the GPR profile is not able to differentiate the individual sedimentary units defined in the trench. This is due to subtle lithological differences that are beyond the level of detection of the geophysical methods.

Similar geophysical signatures were observed in trench T1, namely (1) an inverse magnetic gradient dipole centered on the fault (M3 and G3); (2) a general increase in apparent conductivity along the southern side of the fault for the shallowest interval of frequencies, and a narrower anomaly at deeper levels along the 
a Magnetometry

Vertical magnetic gradient

Residual magnetic anomaly

\section{b Electromagnetic (EM)}

Apparent susceptibility $65 \mathrm{KHz}$ (shallow interval)

\section{Apparent conductivity}

$65 \mathrm{KHz}$ (shallow interval)

. . . . $18 \mathrm{KHz}$ (shallow interval)

. . . .. $5 \mathrm{KHz}$ (deep interval)

\section{Fault at trench}
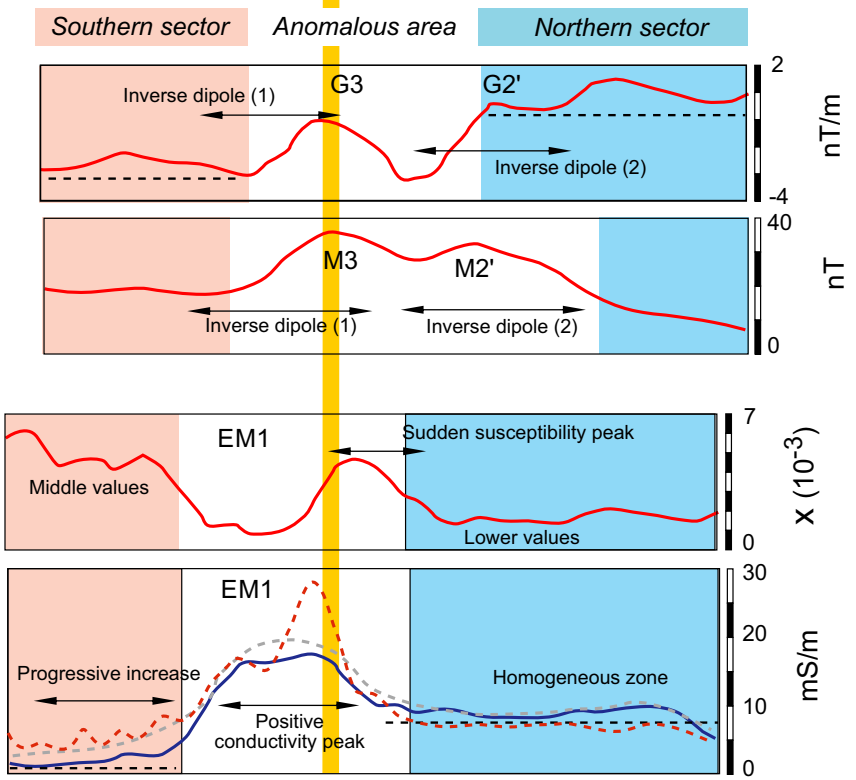

\section{GPR profiles}

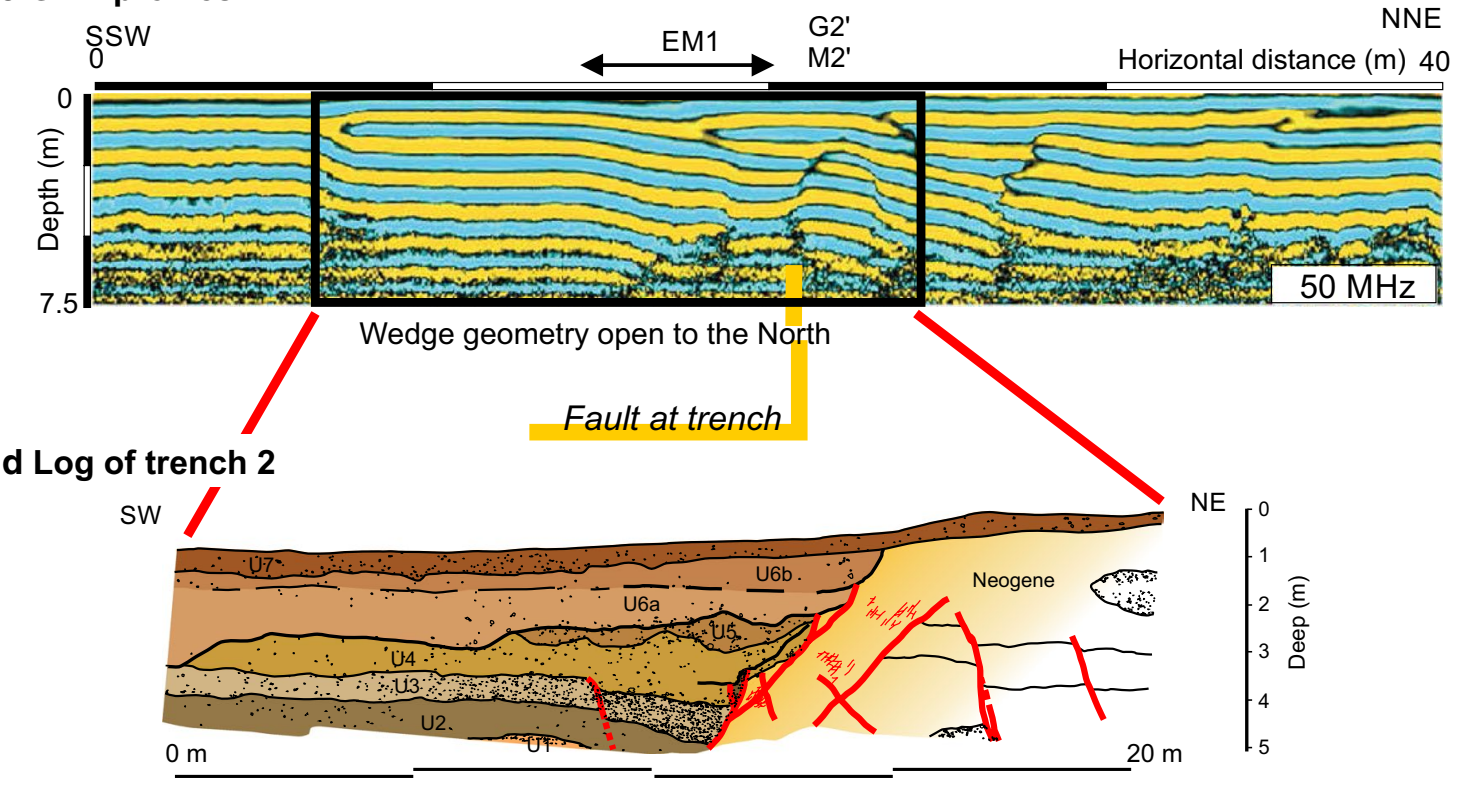

Fig. 12 Comparison between the geophysical profile results and the geological section observed at trench 2 . The plot of magnetometry and EM survey includes the identification of sectors with differential behavior and the anomalies present in the proximities of the fault observed at the trench. a Magnetometry (vertical gradient and residual magnetic anomaly). b Electromagnetic results including appar-

fault (EM1); (3) a slight change of apparent susceptibility values with a general concave geometry; and (4) lateral net changes (interruptions) in GPR profiles at the deepest reflectors, and hyperbolic anomalies and reflector dip changes near the fault in the shallowest part of the GPR profiles. ent susceptibility for the shallowest frequency $(65 \mathrm{kHz})$ and apparent conductivity for distinct frequency devices $(65,18$ and $0.5 \mathrm{kHz})$. c GPR profile (50-MHz antenna) surveyed prior to trench excavation. d Geological $\log$ of trench 2, which has been rotated for facilitating its comparison with the GPR profile. Fault position is marked by a yellow line in the geophysical sections

Trench observations were fundamental to (1) correlate the horizontal reflectors in homogeneous portions of the GPR profile with the clastic units outside of the faulted zone, (2) confirm the reflectors dip variations observed in GPR profiles in the vicinity of the fault (e.g., rollover anticline) and (3) constrain the anomalies in the migrated 
Table 1 Resume of the magnetic susceptibility measurements carried out in $\mathrm{El}$ Hocino area

\begin{tabular}{llrrr}
\hline Unit & \multicolumn{3}{l}{ Magnetic susceptibility $\left(\times 10^{-6}\right)$} & \\
\cline { 2 - 5 } & Lithology & Range & Mean & Standard deviation \\
\hline Agricultural soil & Clays & $55-85$ & 48.08 & 17.16 \\
Pediment & Sandstone and clay (matrix) & $50-100$ & 79.75 & 15.27 \\
Neogene & Sandstone & $70-350$ & 207.65 & 245.95 \\
& Marl & $80-240$ & 146.35 & 43.90 \\
& Clay & $90-230$ & 144.19 & 47.81 \\
\hline
\end{tabular}

profiles to the fault location. Moreover, electromagnetic anomalies exhibit a tight correlation with trench observations with the northeastern limit of the apparent conductivity anomaly near the surface and the narrower anomaly at depth corresponds to the fault location. This pattern corresponds in the GPR profile to the northwards-opening wedge adjacent to the fault.

During the palaeoseismological trenches surveys, magnetic susceptibility measurements were taken with a field susceptometer for the different stratigraphic units (Table 1). Results indicate magnetic susceptibility values ranging from 50 to $35010^{-6}$ SI. Surficial soils show similar values at both sides of the fault, while units under this cover have different values in both blocks of the fault. Values from the footwall block (Neogene rocks) range from 70 to $35010^{-6} \mathrm{SI}$ ), and Quaternary units in the hanging-wall block range from 50 to $10010^{-6}$ SI. Magnetic dipoles or vertical gradient monopole are related to these changes of susceptibility. The geometry of the magnetic dipoles shows a sharp geometry with high slope rate, which is compatible with near-surface anomalous elements. However, this anomaly cannot be explained solely by the above-mentioned variations of susceptibility at superficial conditions. In this sense, for explaining the anomalies, amplitude and higher susceptibility changes are expected to be present under the measured and analyzed materials at the trenches.

\section{Discussion}

Geophysical anomalies are related to changes in physical properties between and within underground units. Such changes may be related to sedimentological variations, strata lateral continuity, deformed strata or tectonic structures (e.g., faults). Different geophysical techniques are sensitive to different physical properties, and dipping discontinuities can be interpreted as either a fault, a preferential path for fluid flow or a boundary between contrasting sedimentary units. In addition, variations within alluvial or colluvial deposits might be related to fault activity and therefore can act as indirect indicators of the fault location.

We infer that the main NW-SE anomaly depicted by the different geophysical techniques correlates with the main fault trace (southern trace of the Concud Fault). This correlation was corroborated by the comparison with the trench exposures, and helps establish the lateral continuity of the Concud Fault, by using the extension of the anomalies to map its trace when the fault is buried by recent sediments (Fig. 13). The geophysical analysis evidenced other anomalies mainly identified through the magnetometry analysis, but also evident to a lesser extent, on the EM data; these anomalies may be related to the presence of other tectonic structures (Fig. 13). Thus, south of anomalies G2-M2, and within the EM1 anomaly, two sets of magnetic anomalies $\mathrm{M} 2^{\prime}-\mathrm{G} 2^{\prime}$ and M3-G3 represent a slight change in orientation and a split of the anomaly into two subparallel traces. We interpret this relation to indicate the existence of a subsidiary fault strand southwest of the main strand similar to secondary strands observed along the Concud Fault near Barranco del Monte gully.

Some of these structures have a subtle topographic expression, suggesting that they may have been associated with surface faulting. These structures also produce variations in apparent conductivity (similar to those observed in syn-tectonic sediments), as well as dipoles in magnetometry that correlate with sharp variations in underground materials. In the central part of the study area, a NNESSW tending linear anomaly (M1 and G1) occurs along the NE-SW oriented gully and coincides with the site where the $\mathrm{G} 2$ and $\mathrm{M} 2$ anomalies split into the $\mathrm{M} 2^{\prime} / \mathrm{G} 2^{\prime}$ and $\mathrm{M} 3 /$ G3 anomalies. The M1/G1 anomaly may indicate either the presence of a NNE-SSW fault, a paleo-relief feature on the Triassic sandstones underneath the pediment or an effect due to the gully presence modifying near-surface moisture conditions. From these hypothesis, we were unable to discriminate which is the correct.

The integration of different techniques leads to improved and more realistic interpretations than those that would have been provided by using a single technique. Each method highlights different and unique characteristics of the buried geological structure and stratigraphy details. In the case of GPR, the profile discontinuities delineated the location of the fault and the stratigraphic relations indicative of tectonic deformation, although centimetric scale details could not be resolved. In this study, the GPR sections globally exhibit multiple offsets that define the trace 
a Topography and geophysical anomalies

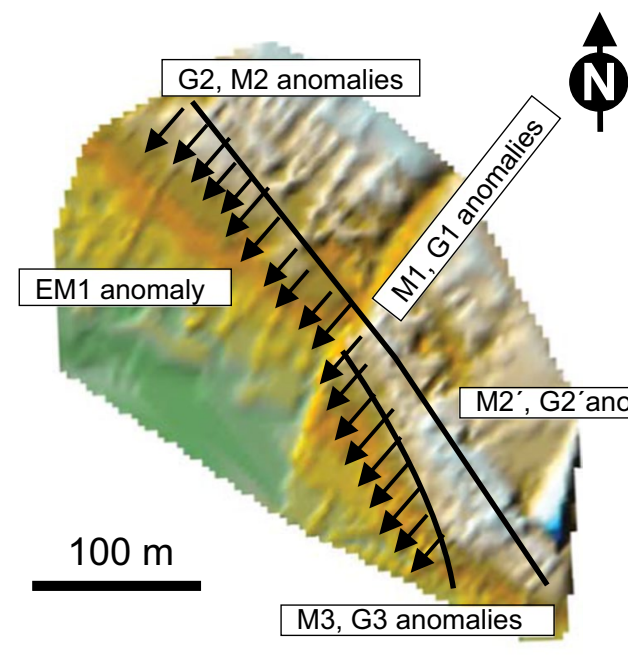

b Geological-geophysical mapping

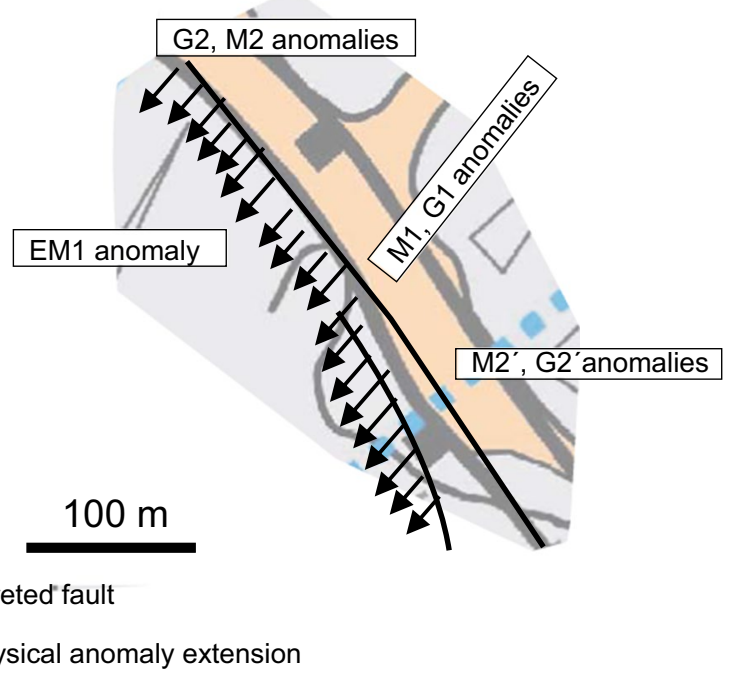

Fig. 13 a Main anomalies observed by the different techniques plotted on the topographic relief image. b Location of traces of the Concud Fault inferred from the geophysical and trenching investigation

of the Concud normal fault. Within the downthrown block, the GPR sections showed bending of the lowermost layers, defining a rollover monocline, while the upper layers evidenced a wedge shape open toward the fault, both features being related to active deformation. Comparison of these profiles with the geological relationships observed in the trenches confirms that GPR profiling is valuable for locating buried faults and inferring structural features associated with tectonic activity as shown in other studies (e.g., Wyatt et al. 1996; Demanet et al. 2001a; Louis et al. 2002; Khan et al. 2013).

The amplitude of the observed magnetic anomalies exceeds what is obtained in the field measurements at the surface and in trenches. This indicates that, in addition to the contrast in susceptibility between the individual stratigraphic units, the anomalies reflect a deeper, more planar and steep dipping discontinuity which we interpreted as corresponding to the fault. If we consider the frequency of the electromagnetic anomalies, we observed that the widest anomaly corresponds to the shallowest depth of penetration and correlates with the stratigraphic units that have been affected by faulting. For frequencies reaching deeper, the anomalous peak becomes narrower, constraining in a tight pattern the fault and it is less affected by the syn-tectonic stratigraphy.

Converse to faults acting as electric conductors (e.g., Hartvich and Valenta 2011), EM peaks are not located along the trace of the fault discontinuity, but are present within the downthrown block (Figs. 9, 12). The cross-correlation of surveys with different EM frequencies can help to improve the recognition of the fault location: low frequencies evidenced a narrow anomaly closer to the fault, while high frequencies evidenced wider anomalies within the hanging-wall block, which are likely the result of a higher water content and thickness of the Quaternary sediments above the fault. Water concentration in the downthrown block may be ultimately related to both the rollover geometry of pre-tectonic deposits and the wedge shape of the Quaternary syn-tectonic sediments.

\section{Conclusions}

A geophysical survey using a variety of methods was carried out in combination with a paleoseismological study of the Concud Fault near Teruel city, NE Spain. An adequate site for paleoseismological trenching was selected on the basis of a large-scale evaluation of geoscientific data (e.g., field mapping, micro-topography, orthoimagery and the results of the geophysical survey). We identified a main geophysical anomaly trending NW-SE with inverse magnetic dipoles at residual and vertical magnetic gradient, a local increase in apparent conductivity, and GPR profiles reflector interruptions suggesting sedimentary structure perturbations. The spatial distribution of the geophysical anomalies revealed by the correlation of the distinct techniques was then applied to select the site for a paleoseismological trench across the fault.

The correlation of our results with the observations in trenches and natural outcrops of the Concud Fault has 
confirmed that the geophysical anomalies are associated with this structure. Therefore, we were able to extend the mapping of the fault to areas where it was not exposed at the surface. The origin of the anomalies is due to the lateral physical properties contrasts between both fault blocks and to the geophysical variations in the sedimentary materials above and directly adjacent to the hanging-wall block. These anomalies are related to permeability variations within the alluvial deposits, which can be controlled directly and indirectly by active tectonics.

These data illustrate the usefulness of geophysical exploration to detect non-exposed fault traces in the surface at areas where moderate-to-low tectonic activity rates or high sedimentation rates may have resulted in burial of fault traces by sedimentation. In summary, the combined use of different geophysical techniques and a cross-correlated analysis of the results allow the definition of domains where anomalies for different physical properties overlap in space. The study of such anomalies allows the identification of physical variations that can be related to the boundary between fault blocks, or highlights fault activity through the deformation of sedimentary bodies. In some cases, it even allows to recognize detailed characteristics of the structure.

The results obtained in this research confirmed that geophysical surveying (especially using multiple methods) is a valuable tool for imaging tectonic faults in the shallow subsurface in areas of poor exposure or where the fault is subtly expressed or buried. Geophysical prospection is a relatively low-cost, noninvasive technique for assessing fault location, and provides rapid results that can assist in the planning of paleoseismological investigations.

Acknowledgments This research has been financed by projects CGL2012-35662 and CGL2009-13390 of Spanish Ministerio de Ciencia e Innovación-FEDER, as well as by the Aragón regional government (Geotransfer research group) and a PHD grant (FPI-DGA) for Paloma Lafuente. Authors want to acknowledge comments, suggestions and ideas by Rich D. Koehler, Paula M. Figuereido and an anonymous reviewer during manuscript revision.

\section{References}

Alcalá L, Alonso-Zarza AM, Álvarez MA, Azanza B, Calvo JP, Cañaveras JC, van Dam JA, Garcés M, Krijgsman W, van der Meulen AJ, Morales J, Peláez P, Pérez-González A, Sánchez S, Sancho R, Sanz E (2000) El registro sedimentario y faunístico de las cuencas de Calatayud-Daroca y Teruel. Evolución paleoambiental y paleoclimática durante el Neógeno. Rev Soc Geol España 13:323-343

Álvaro M, Capote R, Vegas R (1979) Un modelo de evolución geotectónica para la Cadena Celtibérica. Acta Geol Hisp 14:172-177

Annan AP (2004) Ground penetrating radar: principles, procedures and applications. Sensors and Software INC. Mississauga, Canada 239 p
Arlegui LE, Simón JL, Lisle RJ, Orife T (2005) Late PliocenePleistocene stress field in the Teruel and Jiloca grabens (eastern Spain): contribution of a new method of stress inversion. J Struct Geol 27:693-705

Benson AK, Mustoe NB (1995) Analyzing shallow faulting at a site in the Wasatch fault zone, Utah, USA, by integrting seismic, gravity, magnetic and trench data. Eng Geol 40:139-156

Demanet D, Evers LG, Teerlynck H, Dost B, Jongmans D (2001a) Geophysical investigation across the peel boundary fault (The Netherlands) for a paleoseismological study. Geol Mijnbouw 80(3-4):119-127

Demanet D, Renardy F, Vanneste K, Jongmans D, Camelbeeck T, Meghraoui M (2001b) The use of geophysical prospecting for imaging active faults in the Roer Graben, Belgium. Geophysics 66:78-89

Dujardin JR, Bano M, Schlupp A, Ferry M, Munkhuu U, TsendAyush N, Enkhee B (2014) GPR measurements to assess the Emeelt active fault's characteristics in a highly smooth topographic context Mongolia. Geophys J Int 198:174-186

Ezquerro L, Moretti M, Liesa CL, Luzón A, Simón JL (2015) Seismites from a well core of palustrine deposits as a tool for reconstructing the palaeoseismic history of a fault. Tectonophysics 655:191-205

Fischer T, Štěpančíková P, Karousová M, Tábořík P, Flechsig C, Gaballah M (2012) Imaging the Mariánské Lázně Fault (Czech Republic) by 3-D ground-penetrating radar and electric resistivity tomography. Stud Geophys Geod 56:1019-1036

García Lacosta AI, Pueyo Ó, Arlegui LE, Ezquerro L, Liesa CL, Simón JL (2014) La falla reciente de Sierra Palomera (fosa del Jiloca, Cordillera Ibérica): contribución de la prospección geofísica a la caracterización estructural. $2^{a}$ Reunión Ibérica sobre Fallas Activas y Paleosismología, Lorca, España. p 51-54

Godoy A, Olivé A, Moissenet E, Gutiérrez M, Aguilar MJ, Ramírez J, Aragonés E, Giner J, Portero JM (1983a) Mapa Geológico de España 1: 50.000, hoja $\mathrm{n}^{\circ} 590$ (La Puebla de Valverde). IGME, Madrid

Godoy A, Ramírez JI, Olivé A, Moissenet E, Aznar JM, Aragonés E, Aguilar MJ, Alberdi MT, Giner J, Gutiérrez Elorza M, Portero JM, Gabaldón V (1983b) Mapa Geológico de España 1:50.000, hoja $\mathrm{n}^{\circ} 567$ (Teruel). IGME, Madrid

Gutiérrez F, Gutiérrez M, Gracia FJ, McCalpin JP, Lucha P, Guerrero J (2008) Plio-Quaternary extensional seismotectonics and drainage network development in the central sector of the Iberian Range (NE Spain). Geomorphology 102:21-42

Gwendolyn P, Buchmann TJ, Connolly P, Van Balen RT, Wenzel F, Cloetingh SAPL (2005) Interplay between tectonic, fluvial and erosional processes along the Western Border Fault of the northern Upper Rhine Graben, Germany. Tectonophysics 406:39-66

Hanks TC, Kanamori H (1979) A moment magnitude scale. J Geophys Res 84(B5):2348-2350. doi:10.1029/JB084iB05p02348

Hartvich F, Valenta J (2011) The identification of faults using morphostructural and geophysical methods: a case study from Strasin Cave site. Acta Geodyn Geomater 8(164):425-441

Huang H (2005) Depth of investigation for small broadband electromagnetic sensors. Geophysics 70(6):G135-G142

Huang H, Won IJ (2000) Conductivity and susceptibility mapping using broadband electromagnetic sensors. J Environ Eng Geophys 5(4):31-41

IGN (2010) Servicio de información sísmica del instituto geográfico nacional. http://www.ign.es/ign/es/IGN/SisCatalogo.jsp

Khan SD, Stewart RR, Otoum M, Chang L (2013) A geophysical investigation of the active Hockley Fault system near Houston Texas. Geophysics 78(4):B177-B185

Khesin B (2004) Use of geophysical methods for the solution of environmental problems in Israel. HAIT J Sci Eng B 2(1-2):95-124 
Lafuente P, Rodríguez-Pascua MA, Simón JL, Arlegui LE, Liesa CL (2008) Sismitas en depósitos pliocenos y pleistocenos de la fosa de Teruel. Rev Soc Geol España 21:133-149

Lafuente P, Arlegui LE, Liesa CL, Simón JL (2011) Paleoseismological analysis of an intraplate extensional structure: the Concud fault (Iberian Chain, Spain). Int J Earth Sci 100:1713-1732

Lafuente P, Arlegui LE, Liesa CL, Simón JL (2012) Reply to the discussion by F. Gutiérrez, P. Lucha, J. Guerrero, M. Gutiérrez and D. Carbonel on the article 'paleoseismological analysis of an intraplate extensional structure: the Concud fault (Iberian Chain, eastern Spain)'. Int J Earth Sci 101(2):587-594

Lafuente P, Arlegui LE, Liesa CL, Pueyo Ó, Simón JL (2014) Spatial and temporal variation of palaeoseismic activity at an intraplate, historically quiescent structure: the Concud fault (Iberian Chain, Spain). Tectonophysics 632:167-187

Louis IF, Raftopoulos D, Goulis I, Louis FI (2002) Geophysical imaging of faults and fault zones in the urban complex of Ano Liosia Neogene Basin, Greece: synthetic simulation approach and field investigations. J Electr Electron Eng Spec Issue Oct 2002:269-285

Martín Bello L, Arlegui LE, Ezquerro L, Liesa CL, Simón JL (2014) La falla de Calamocha (fosa del Jiloca, Cordillera Ibérica): estructura y actividad pleistocena. $2^{\mathrm{a}}$ Reunión Ibérica sobre Fallas Activas y Paleosismología, Lorca, España pp 55-58

McBride JH, Stephenson WJ (2003) Preface to contributions to neotectonics and seismic hazard from shallow geophysical imaging. Spec Vol Tectonophys 368:1-5

McCalpin JP (2005) Late Quaternary activity of the Pajarito fault, Rio Grande rift of northern New Mexico, USA. Tectonophysics 408:213-236

Nguyen F, Garambois S, Chardon D, Hermitte D, Bellier O, Jongmans D (2007) Subsurface electrical imaging of anisotropic formations affected by a slow active reverse fault, Provence France. J Appl Geophys 62:338-353

Opdyke N, Mein P, Lindsay E, Pérez-González A, Moissenet E, Norton VL (1997) Continental deposits, magnetostratigraphy and vertebrate paleontology, late neogene of Eastern Spain. Palaeogeogr Palaeoclimatol Palaeoecol 133:129-148

Pavlides S, Caputo R (2004) Magnitude versus faultś surface parameters: quantitative relationships from the Aegean Region. Tectonophysics 380:159-188

Powell JW (1873) Geological structure of a district of country lying to the north of the Grand Canyon of the Colorado. Am J Sci $5: 456-465$

Roca E, Guimerà J (1992) The Neogene structure of the eastern Iberian margin: structural constraints on the crustal evolution of the Valencia trough (western Mediterranean). Tectonophysics 203:203-218

Rubio JC, Simón JL (2007) Tectonic subsidence v. erosional lowering in a controversial intramontane depression: the Jiloca basin (Iberian Chain, Spain). Geol Magazine 144:1-15
Simón JL (1982) Compresión y distensión alpinas en la Cadena Ibérica Oriental. Tesis Doct. Universidad de Zaragoza. Publ. Instituto de Estudios Turolenses, Teruel (1984)

Simón JL (1983) Tectónica y neotectónica del sistema de fosas de Teruel. Teruel 69:21-97

Simón JL, Arlegui LE, Lafuente P, Liesa CL (2012) Active extensional faults in the central-eastern Iberian chain Spain. J Iber Geol 38(1):127-144

Simón JL, Arlegui LE, Ezquerro L, Lafuente P, Liesa CL, Luzón A (2015) Enhanced paleoseismic succession at the Concud fault (Iberian Chain Spain) New insights for seismic hazard assessment. Nat Hazards. doi:10.1007/s11069-015-2054-6

Štěpančíková P, Dohnal J, Pánek T, Loj M, Smolková V, Silhán K (2011) The application of electrical resistivity tomography and gravimetric survey as useful tools in an active tectonics study of the Sudetic Marginal Fault (Bohemian Massif, central Europe). J Appl Geophys 74:69-80

Stirling M, Rhoades D, Berryman K (2002) Comparison of earthquake scaling relations derived from data of the instrumental and preinstrumental era. Bull Seism Soc Am 92:812-830

Suski B, Brocard G, Authemayou C, Consenza Muralles B, Teyssier C, Klaus Holliger K (2010) Localization and characterization of an active fault in an urbanized area in central Guatemala by means of geoelectrical imaging. Tectonophysics 480:88-98

Suzuki K, Toda S, Kusunoki K, Fujimitsu Y, Mogi T, Jomori A (2000) Case studies of electrical and electromagnetic methods applied to mapping active faults beneath the thick quaternary. Eng Geol $56: 29-45$

Vanneste K, Verbeeck K, Petermans T (2008) Pseudo-3D imaging of a low-slip-rate, active normal fault using shallow geophysical methods: the Geleen fault in the Belgian Maas River valley. Geophysics 73(1):B1-B9. doi:10.1190/1.2816428

Vegas R, Fontboté JM, Banda E (1979) Widespread Neogene rifting superimposed on alpine regions of the Iberian Peninsula. In: Proceedings symposium evolution and tectonics of the Western Mediterranean and surrounding areas, EGS, Viena. Instituto Geográfico Nacional, Madrid, Special Publication 201, pp $109-128$

Wells DL, Coppersmith KJ (1994) New empirical relationships among magnitude, rupture length, rupture width, rupture area, and surface displacement. Bull Seism Soc Am 84:974-1002

Wise DJ, Cassidy J, Locke CA (2003) Geophysical imaging of the quaternary Wairoa North Fault, New Zealand: a case study. J Appl Geophys 53:1-16

Wyatt DE, Waddell MG, Sexton GB (1996) Geophysics and shallow faults in unconsolidated sediments. Ground Water 34(2):326-334 